\title{
Women in glaciology, a historical perspective
}

\author{
Christina L. HULBE, ${ }^{1}$ Weili WANG, ${ }^{2}$ Simon OMMANNEY ${ }^{3}$ \\ ${ }^{1}$ Department of Geology, Portland State University, PO Box 751, Portland, Oregon 97207-0751, USA \\ E-mail: chulbe@pdx.edu \\ ${ }^{2}$ NASA Goddard Space Flight Center, Code 614.1, Greenbelt, Maryland 20771, USA \\ ${ }^{3}$ Emeritus Associate, Scott Polar Research Institute
}

\begin{abstract}
Women's history in glaciology extends as far back in time as the discipline itself, although their contributions to the scientific discourse have for all of that history been constrained by the sociopolitical contexts of the times. The first Journal of Glaciology paper authored by a woman appeared in 1948, within a year of the founding of the Journal, but it was not until the 1980s that women produced more than a few percent of Journal and Annals of Glaciology papers. Here international perspectives on women's participation in the sciences are presented in order to establish an economic and sociopolitical context for stories of women 'pioneers' in glaciology and a frame in which to discuss women's persistent under-representation relative to men. We find that the experiences of individual glaciologists mirror women's experiences in higher education and the sciences as a whole. The existence of both positive and negative trends in women's participation in the sciences suggests caution in the interpretation of recent positive trends for women's participation in glaciology.
\end{abstract}

\section{HISTORICAL CONTEXT}

\subsection{Histories of women in science}

Surveys of famous women have been assembled since at least the 14th century (Schiebinger, 1987). Christine de Pizan wrote about women's innovations in the sciences in her allegory, The book of the city of ladies (de Pizan, 2004 [1405]), but the first encyclopedia of women in a scientific discipline, Jérôme de Lalande's Astronomie des dames, did not appear until 1786, a time when European intellectuals had become interested in social justice and equity. In his 1830 history of women in the medical disciplines, Christian Friedrich Harless theorized that men were drawn to science in order to discover the laws of nature while women were searching for expressions of love in the natural world. His was the last treatise to include Roman goddesses as important personalities in the history of women.

By the late 19th century, proponents of women's participation in science had shifted from compiling lists of female scientists and their accomplishments to analyzing the circumstances limiting their access to the academy. In the first detailed book on this subject, Father John A. Zahm, C.S.C. argued pseudonymously (Mozans, 1913) that contrary to popular thought at the time, women were not limited by biology but by access to education and opportunity. The first historians to write about women in science produced biographies in the 'great man' tradition, leaving issues unique to women in the sciences unexplored (Schiebinger, 1987). In such treatments, events like Kathleen Lonsdale's 1945 election to the Royal Society of London or Liz Morris's 1987 arrival in Antarctica as a British Antarctic Survey (BAS) team member are hailed as transformative, yet as a group, women remain under-represented nearly two centuries after they gained access to higher education (Kuwahara, 2001; European Commission, 2009a; Canizares and Shaywitz, 2010). This framework is also problematic because it assumes acceptance by ranking males as an appropriate metric by which to evaluate female accomplishments, obscuring the negotiated nature of women's participation and progress. More careful examination of the history of women in science reveals persistent themes across time and national borders: women's participation both waxes and wanes due to identifiable economic and social forcings. It is in this context that the stories of individual female glaciologists and women's persistent under-representation in the physical sciences, including glaciology, must be understood.

\subsection{The longue durée}

Education, whether formal or informal, is the foundation for scientific achievement. Names of female scholars have been passed down since antiquity, but the record is spare (Meschel, 1992; Ogilvie, 1993; Sharma, 2000). While cultural biases may affect whose names and accomplishments persist in the historical record, girls' and women's access to education has long trailed behind boys' and men's access. When women's education is valued, it is often for benefits external to the individuals themselves (e.g. public health), and everywhere women's access to education floats on a socio-political tide (Rossiter, 1998; Fuchs and others, 2001). Both progress and regress in women's education can be found along a timeline that spans millennia and national borders, and varies with economic status and ethnic identity.

Women have long sought access to education and have long created alternatives where they found access denied. Women in medieval Europe were able to engage in scholarly studies within convents. The creation of cathedral schools and transition to formal universities in the High Middle Ages reduced scholarly opportunities because these new institutions were by design closed to women (Shahar, 2003, p. 5051). Only in exceptional cases, primarily in Italy and Germany, did women of the Middle Ages study at university (Schiebinger, 1987; Ogilvie, 1993, p.6-9). Craft guilds offered an alternative source of training as did, for the upper classes, the courts and salons of the Renaissance (Campbell, 2007). Indeed, the Renaissance was a rebirth for female intellectuals just as it was for men, although women's subordinate social status persisted and access to education varied widely across national borders (Ogilvie, 1993, p. 10-13).

The rise of scientific academies in the 17th century presented a new challenge to female scholars. Membership 
was closed to women (except in Italy; Schiebinger, 1991, p. 26), even to well-established scientists, yet membership conferred status and authority. The election of Marjory Stephenson and Kathleen Lonsdale to the Royal Society of London came as the culmination of years of campaigning for the place of women in that society (Mason, 1992). William Astbury, a Lonsdale contemporary and one of the 12 Fellows who put her name into nomination, wrote in 1943 to Lawrence Bragg, a reluctant supporter of the women's membership in the Royal Society,

Many thanks for your letter. I suppose the suggestion was bound to come sooner or later that women should be put up for the Royal Society, and once that is accepted I don't think you could find a woman candidate more likely than Mrs. Lonsdale to be successful. I should put her at quite the best woman scientist that I know - but that probably is as far as I am prepared to go, because I must confess that I am one of those people that still maintain that there is a creative spark in the male that is absent from women, even though the latter do so often such marvellously conscientious and thorough work after the spark has been struck.

(Mason, 1992)

Drs Lonsdale and Stephenson were nominated and elected in 1945, nearly 300 years after the Society's founding.

Enlightenment-era social analysis both questioned and reinforced long-standing ideas regarding the role of women in society. While Rousseau (1763) and his peers conscripted women's education to the service of men, others understood the new idea of human progress differently, making the case that women's equality and women's education were an essential step in societal evolution (Murray, 1790; Condorcet, 1791; de Gouges, 1791; Wollstonecraft, 1796). Finding themselves nevertheless unwelcome in the university and scientific community, 18th- and early 19th-century women found alternatives, as had their predecessors in centuries before. In England, economically advantaged women organized 'blue stocking' societies for the purpose of scholarly discussion. The French salon continued to provide an intellectual environment for women of economic means (Goodman, 1989) while cafés provided a measure of democratization. Similar doors opened elsewhere in Europe (Messbarger, 2002), but formal education remained out of reach. William Whewell asserted, in his positive review of Mary (Fairfax) Somerville's definitive On the connexion of the physical sciences (1824), that few other women would be able to understand the material. Such views remained common long after women gained entry to the academic sphere and the professional scientific laboratory.

As 19th-century women began to gain access to university classrooms, they were in most cases admitted as auditors without the opportunity to earn a degree. Again, women found alternatives. 'Steamboat ladies', who had studied at Oxford and Cambridge but were denied degrees due to their sex, travelled to Trinity College, Dublin, where university degrees were awarded ad eundem. As a group, women were formally admitted in the mid-19th century and later as students who might be awarded university degrees. For example, women gained entry in 1833 in the United States, 1905 in Argentina, 1908 in Germany, 1937 in Iran and 1945 in Japan (Etzkowitz and Kemelgor, 2001). Female scholars migrated to countries where access came relatively early, for example to Switzerland (1867) and France (1881). Russian women of the 1860s-70s were among the most mobile of the degree-seeking migrants (Koblitz, 1988). These pioneers of women's education in Europe were among the first female students admitted for degrees, and their doctorates were the first for women in mathematics, chemistry, biology and medicine (Goegg, 1884, p. 388-389).

By the 1920s, the doors of the university were open to women throughout much of the industrialized world. Demographic changes due to the First World War led some governments to encourage female education as a way to build economic capacity. Pedagogical training became a women's domain in many countries during this time and women were relatively well represented in medical programs as well. These patterns persist to the present day. The trend toward broader participation by women in the university and the professional workplace would in many countries be reversed during the Great Depression, as women were faulted for taking the place of men in the workforce (Tournier, 1973; Alexander, 2000; Hutton, 2001, p. 323-364).

In China, women's scholarly interests were for millennia constrained by a strict social order founded in Confucian teachings, summarized neatly by a proverb attributed to the time of the Ming Dynasty: 'the lack of talent is a virtue in women' (Ho, 1995). The oppression of women varied regionally, however, and, as in the West, some women found scholarly refuge in monastic life and some found opportunity as scientific assistants to husbands, brothers and sons (Meschel, 1992). By the end of the 19th century, reform-minded scholars were promoting universal education as essential to modernization (Qiao and Liu, 2009), and by 1917 advocates for women in the New Culture Movement welcomed the first Chinese institution of higher education for women, Beijing Female Normal School Senior Branch (Wang, 1999, p. 9; Edwards, 2000).

Chinese women's access to higher education and opportunity for scientific studies gained legal protection with the 1949 founding of the People's Republic of China. Most schools became co-educational at that time, although some urban elite secondary schools, the gateway to advanced training, remained gender-segregated until the 1970s (Liu and Carpenter, 2005). Despite the egalitarian goals of the government, attitudes to women's role in society differed between urban and rural areas, and women everywhere were expected to carry the burden of household chores while also fulfilling their work duties outside the home (Andors, 1975; Diamond, 1975; Ngo, 2002). In this, their experiences were no different than those of Western women (Lonsdale, 1970; Hutton, 2001, p. 209; Schiebinger and Gilmartin, 2010). Nevertheless, some women, primarily urban women, gained access to higher education, and by 1960 more than $20 \%$ of university students were women, and $23 \%$ of members of the Chinese Academy of Sciences were women (Meschel, 1992).

The Cultural Revolution brought additional educational reform to China (Unger, 1980) as a new emphasis was placed on vocational training, critical analysis and creativity. Women continued to fare relatively well during this time (Wu, 2008). After the Cultural Revolution ended in 1976, reforms began anew. Entrance examinations at the secondary level became the gateway into a system with more choices among university-preparatory, vocational and technical schools, and this selection step has had the effect of filtering students by their sex. Today, all but the highestscoring girls are more likely than boys to make a pragmatic 
school choice in favor of a shorter pathway to more certain employment and marriage. That is, young women tend to select against the university track, where female graduates face more uncertainty than male graduates, and in favor of vocational training (Broaded and Liu, 1996; Liu and Carpenter, 2005). At the end of 2008, about $6 \%$ of members of the Chinese Academy of Sciences were women (40 of 692), a decrease that reflects the changing expectations and aspirations of secondary-school students.

Despite vocal prejudice against them (Fuchs and others, 2001), German women managed to make modest gains after universities opened to them officially in 1908. These gains were lost in the 1930s, as the Third Reich turned away from the relatively liberal policies of the Weimar Republic. Women were forced out of the university and back into the home (Tournier, 1973; Hutton, 2001, p. 308), and those who wished to work outside the home were required to remain single (work agreements contained the ZölibatsKlausel, or celibacy clause). Women's participation in higher education did not start to recover in West Germany until educational reforms began in the 1960s (Tournier, 1973).

A similar return to 'traditional' cultural values stalled women's progress in 20th-century Japan. The need for women's labor during the Russo-Japanese war (1904-05) opened doors through which girls entered school and women entered the workforce (Nolte, 1986). Women's access to education had been facilitated by the Meiji government, although, as elsewhere, the primary goal in educating girls and women was to prepare them to be 'good wives and wise mothers' (Kuwahara, 2001), not professionals. Following the Second World War, political and business leaders sought stability in a return to the social structure of the past (Nolte, 1986; Kuwahara, 2001). In 1958, the Ministry of Education promulgated a middle school standard in which girls studied home economics (or 'domestic science') and boys studied technology. Junior colleges, established in the 1950s, became a de facto women's track in higher education (Harada, 1993). These colleges were not comprehensive, and pedagogical training, domestic science and the humanities dominated curricula leading to occupational certificates and licenses.

Economic changes in the 1970s presented new opportunities for women as Japan turned away from heavy industry and toward high technology. The labor market began to favor flexibility, and a contingent labor force emerged, offering the possibility of accommodation for women's domestic obligations (Fujimura-Fanselow, 1985; Kuwahara, 2001). Women gained some access to science and engineering jobs in this relatively unstable environment but were typically viewed as secondary and suited only to work as laboratory assistants (Coleman, 1999, p. 128-149; Kuwahara, 2001). A decline in the number of secondary school students interested in science and technology and an impending labor shortage in the 1990s led to active encouragement of women to pursue university degrees in these fields (Kuwahara, 2001).

Where they were able to gain admission, 'pioneer' women in science often found themselves limited to ghettoized tasks and low pay (Talbot, 1910; Rossiter, 1980; Etzkowitz and Kemelgor, 2001; Fuchs and others, 2001; Plonski and Saidel, 2001). The rapid expansion of low-wage work for women in astronomical observatories of the late 19th century is well known, but the same phenomenon characterized other disciplines as well. In geology, women worked as illustrators and sample collectors, but the products of their labors were reported by male scientists and the women usually went without credit (Aldrich, 1993). Women found professional work in the life sciences, and in home economics or 'sanitary science', where interest in chemistry was directed. Pedagogical studies were also encouraged. Women in Mexico gained access to higher education as early as 1890, but were directed toward teacher training at 'normal schools', where 20 years later they accounted for $78 \%$ of the student population (Cortina, 1989). Both academic advisers and the popular media encouraged women toward these 'feminine' disciplines (Rossiter, 1974, 1980), but upon arrival women found their options for career advancement limited and subject to change according to men's preferences. For example, women in the USA and UK who entered university departments of geography during the Second World War found their contracts not renewed and new positions more difficult to obtain after the war ended and men returned to the university (Monk, 2004; Maddrell, 2008). Women were aware of the inequities and prejudice (Hayes, 1910; Talbot, 1910), but found ways to take advantage of opportunities where they arose.

\section{WOMEN'S WORK}

It was into an often unwelcoming academy and with restrictive social expectations (Hansson, 2009; Lewander, 2009) that women of the 19th and 20th centuries embarked into alpine and polar research, and into the many areas of specialization within glaciology. It is not possible to profile here all the pioneer women in glaciology and, indeed, a simple encyclopedic accounting offers little substance for analysis. The women presented here are selected with a view toward geographic diversity and data that add detail to persistent themes in women's representation in the sciences.

Practical, methodical observations of snow and ice have certainly been conducted as long as people have lived and travelled in cold regions, but the history of glaciology as a well-defined scholarly discipline is relatively short. Indeed, a spirited debate regarding its very disciplinary scope can be found in International Glaciological Society (IGS) correspondence at the time of the founding of the Journal of Glaciology (Wood, 1986, p. 26-28). Women's participation in glaciological studies, as represented in the published scientific literature, can be traced back to at least 1902 (Ogilvie, 1902), although it should be noted that Mary Somerville (1780-1872) was the first scientist to write about the importance of solar radiation to energy balance at Earth's surface (Somerville, 1848). The first Journal of Glaciology paper co-authored by a woman appeared within a year of the Journal's founding (Owston and Lonsdale, 1948), but female authors remained the exception for much of the Society's history and account for less than one in five author instances in the Journal and Annals of Glaciology today (Fig. 1). Most of the growth in women's authorship in the two IGS periodicals occurred in the 1980s and later.

\subsection{Expedition}

The notion of 'pioneers' in glaciology is complicated where people have been living with and observing snow and ice for millennia, and by the different goals of exploration and scientific investigation (Robinson, 2006). Antarctica's remoteness and hostile environment make the case for 

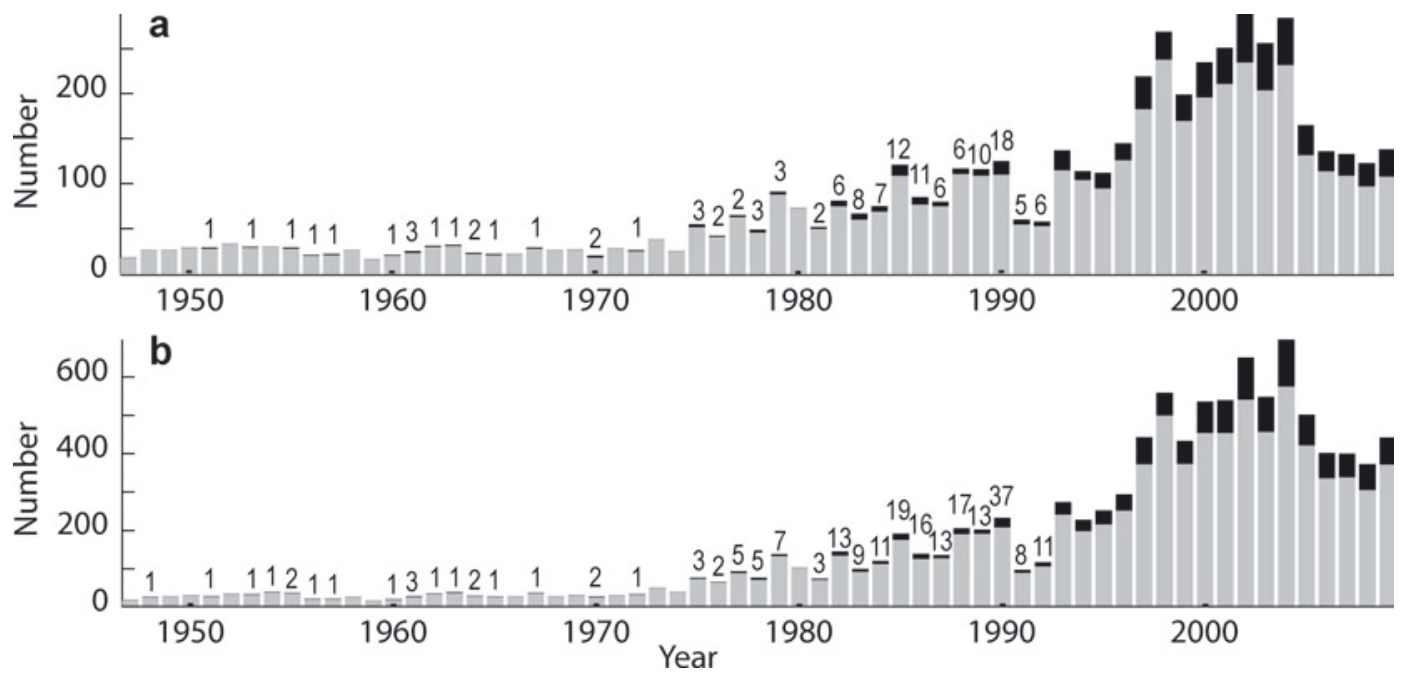

Fig. 1. Contributions to the Journal and Annals of Glaciology from 1947 to 2009, classified by author sex. Grey bars indicate male authors and black bars indicate female authors, and the total number of female authors is indicated until it is consistently larger than 10 . (a) Classified first authorships. (b) All classified authorships. The author database was provided by the IGS in August 2010. The author classification is geographically diverse and we were able to identify author sex for approximately $72 \%$ of all papers and $70 \%$ of first authors. Emphasis was placed on classifying authors cited for more than one paper.

Antarctic pioneers relatively clear, although as we look backward in time, our vision is limited to only those women whose stories or work survive in the written record. Prior to the 20th century, professional pathways for women were limited. Personal wealth afforded opportunity to step outside expected activities and occupations, as did, occasionally, marriage.

The Western record of women in the Antarctic region begins in 1773 with Louise Séguin, who sailed, undisclosed on the ship's manifest, with Captain Yves Joseph de Kerguelen aboard the Roland. Séguin's voyage is known only because it cast a shadow on Kerguelen's career (Chipman, 1986). Women make infrequent appearances as captains' wives among the sealing and whaling parties that followed. These pioneering women are recorded primarily as curiosities in men's narratives, where their fortitude is cited as exceptional and attributed to the exemplary nature of their husbands (Hansson, 2009). Nevertheless, European women were sailing, going ashore on sub-Antarctic islands and making observations of the natural world around them by the 1850s. The first European woman to sight the Antarctic continent was a castaway found with three men on Campbell Island in January 1839. The four were taken on board the Enderby Brothers ships Eliza Scott and Sabrina, and continued south to within sight of the continent. The woman's name was not recorded in the captain's journal.

The women of Remote Oceania were sailing and navigating the Pacific centuries before European sailors arrived (D'Arcy, 2006, p. 90; Huffer, 2008). Some of these women may have ventured to the sub-Antarctic to witness icebergs and snowy islands, as the great explorers Ui-terangiora and Te Ara-tanga-nuku are reported to have done in about 650 and $1000 \mathrm{CE}$, respectively (Ariki-tara-are, 1919). Unfortunately, oral history transcriptions were influenced by the gendered nature of early anthropological research, and details regarding women's participation in Pacific navigation have been lost (Huffer, 2008).

The first account of the sub-Antarctic in a woman's own voice is the journal of Abby Jane (Wood) Morrell, who sailed aboard the schooner Antarctic with her husband Captain
Benjamin Morrell (Morrell, 1833). In the conclusion to her narrative of three years at sea, Morrell expresses a keen awareness of both her skill as an observer and what lack of access to formal scientific training has cost her:

The great difficulty we women feel in collecting information, is the want of order and classification of our thoughts ... I doubt whether a scientific observer would have had more thoughts than passed through my teeming brain; but he would have known how to arrange them, and have drawn conclusions tending to establish known truths, or elicit new ones; while whatever observations or conclusions I might make were liable to be dispersed for not knowing where to preserve them. The unstudied and unpracticed mind, however, observes many things that might escape the notice of the best educated.

(Morrell, 1833, p. 223-224)

The first women to winter over on the Antarctic continent travelled south, like Abby Jane Morrell, in the company of their husbands. Edith M. 'Jackie' Ronne and Jennie Darlington helped establish a station on Stonington Island in Marguerite Bay on the Antarctic Peninsula as members of the Ronne Antarctic Research Expedition of 1946-48. Both women wrote accounts of their journeys that conformed to the gender order of the era, although Ronne was more optimistic about women's (nurturing) role in polar exploration than was Darlington (Ronne, 1950, 2004; Darlington and Mcllvaine, 1957). Jackie Ronne was an active participant in the work of the expedition, filing news reports of the team's progress, learning to operate the expedition's seismic observation equipment, and making tide height observations at Marguerite Bay (B. Shoemaker, unpublished information).

Some of the first women to publish their observations of snow and ice in the scientific literature were part adventurer and part scientific observer, not unlike their male contemporaries. Fanny Bullock Workman, traveller, mountaineer and surveyor, reported her observations of glaciers in the Himalaya and Karakoram to the Royal Geographical Society and the Geographical Society of America, and wrote popular accounts of her travels in that region. Elizabeth 


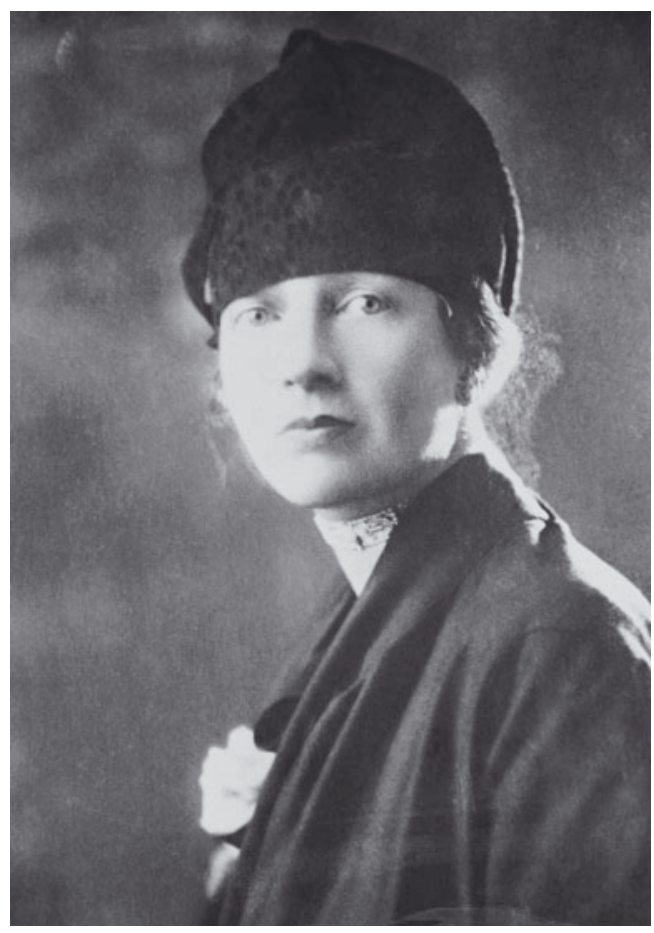

Fig. 2. Louise Arner Boyd, 1928. (C) Corbis

(Fulton) Parker and Mary Morris (Vaux) Walcott both arrived to alpine studies as tourists, but as is the case for many glaciologists, the mountain landscapes captured their imaginations and changed the course of their lives. None of these women had the advantage of formal scientific training, yet all contributed to glacier studies at the turn of the 20th century.

\subsubsection{Fanny Bullock Workman}

Born to a wealthy family in Worcester, Massachusetts, USA, Fanny Bullock (1859-1925) preferred adventure to the quiet life her social status might have conferred. Bullock attended finishing school in New York and Europe before returning to Worcester, where she met and married William Hunter Workman, a physician and avid mountaineer, in 1881 (James and others, 1971, p. 672). Their daughter Rachel was born in 1884. An 1886 trip to Europe, during which Bullock Workman made her first Alpine ascents, changed the course of the family's life. Dr Workman gave up his medical practice, the couple took up bicycle touring, and Bullock Workman began to write popular accounts of their travels through Europe, the Mediterranean and the Far East. By the turn of the century, the Workmans had moved on to a new form of travel adventure, mountaineering. Fanny learned the essentials of surveying, and the Workmans became alpine expeditioners, folding measurements of glaciers and mountain peaks into their work and publishing the results in the scientific literature and popular books (Bullock Workman and Workman, 1900; Bullock Workman, 1906, 1912).

The Workmans' daughter Rachel (later Lady MacRobert; 1884-1954) earned a degree in geology at the University of London in 1911. She went on to postgraduate research as a member of Imperial College, publishing papers on the igneous petrology of Scotland and Sweden (Workman MacRobert, 1914; Burek, 2009), regions in which she also investigated glacial geomorphology. Rachel Workman was among the first women elected, 112 years after its founding, to Fellowship in the Geological Society of London. She had campaigned for this access and, upon gaining it, wrote to her husband, Sir Alexander MacRobert,

I am very much amused at the first list of 16 women admitted to the F.G.S. There are one or two notabilities the others merely wives. It is obvious why they were admitted at this juncture. They are badly needing additional subscriptions so the female subscriber has a financial value if none other. Poor downtrodden race! (Burek, 2009, p. 395)

In this, she echoed her mother's sensibility about women's status in the sciences and society. Lady MacRobert is perhaps most well known for 'MacRobert's Reply', a Short Stirling bomber purchased by the Royal Air Force with a donation she made in honor of her two sons lost during the Second World War.

\subsubsection{Elizabeth Parker}

After earning a teaching certificate at the Truro Normal School in Nova Scotia, Canada, 18-year-old Elizabeth Fulton (1856-1944) married Henry John Parker and soon moved to Winnipeg, where she participated in local literary societies and raised four children (Thomas, 1948). A complaint in 1904 to the Manitoba Free Press about poor coverage of literary events resulted in a job offer and a 36 year career in journalism, a post that would later facilitate her campaign for the creation of the Alpine Club of Canada (Winnipeg Free Press, 1944). Parker had developed a lifelong interest in the Canadian Rockies and mountaineering during an 18 month trip to Banff with her children. Collaborating with western land surveyor Arthur Wheeler, Parker wrote the text for the first book detailing the glaciers and other features of the Selkirk Mountains, Canada (Wheeler and Parker, 1912). Her advocacy led the Canadian Alpine Club to be the first such organization to admit women.

\subsubsection{Mary Morris Walcott}

Mary Morris (Vaux) Walcott (1860-1940) is remembered today for both her botanical illustrations and the glacier and mineral studies she conducted with her brothers in the Canadian Rockies. Mary Vaux began studies as a watercolorist at the age of eight, continuing her training as an illustrator via private tutoring and as a student at the Friends Select School in Philadelphia, USA, which she attended from 1869 to 1879 . Following the death of her mother in 1880, Vaux assumed the role of household manager and worked on the family dairy farm. An 1887 trip to the Canadian Rockies with her father and brothers, lawyer and mineralogist George Vaux, Jr, and architect William Vaux, so inspired the family that they returned repeatedly, photographing and measuring the glaciers of the Selkirk Mountains, publishing the results of their work (Vaux, 1911, 1913; Vaux and Vaux, 1911) and showing their photographs in juried exhibits of the Photographic Society of Philadelphia. The trips were more than a summer adventure for Mary Vaux; they opened the door to her career as a botanist and botanical illustrator (Walcott, 1925).

\subsubsection{Louise Arner Boyd}

Louise Arner Boyd (1887-1972; Fig. 2) began her Arctic expeditions in an attempt to find Roald Amundsen after he disappeared in his own 1928 attempt to find the explorer Umberto Nobile. Boyd did not find any evidence of 
Amundsen's fate, but her interest in the Arctic led to a series of scientific expeditions to northeastern Greenland and the Arctic Ocean between 1931 and 1938. Her scientific parties observed glaciers, fjords and adjacent ocean regions. Boyd took thousands of photographs, documented carefully for use by American Geographical Society cartographers. In her 1932 report on an expedition to Franz Josef and King Oscar Fiords in eastern Greenland (Boyd, 1932), she remarked on differences from past maps, suggesting '[the] possibilities of glacial retreat should not be overlooked'. Bathymetric observations made during Boyd's expeditions (Boyd, 1948) led to such discoveries as a sea-floor ridge between Jan Mayen and Bear Islands. In 1941 she was sponsored by the United States National Bureau of Standards to study the effects of magnetic fields on radio communications in the Arctic. Boyd's papers and books on her work in the Arctic and elsewhere were well received in the scientific community (JMW, 1935; Hobbs, 1936).

\subsection{Adaptation}

Dr Ida Ogilvie and Ebba Hult De Geer, both of whom studied geology at the turn of the 20th century, made contributions in the area of glacial geology by adapting themselves to fit the opportunities available to women at the time. Ogilvie, a pioneer in women's geological education in the United States, turned to glacial geology at the turn of the 20th century, a time when the research field was wide open. Hult De Geer began her studies on varves and geochronology as an assistant to her husband, the eminent Quaternary geologist Gerard De Geer (Bailey, 1943), a framework that provided access but limited the recognition her work received.

\subsubsection{Ida Ogilvie}

Ida Ogilvie's (1874-1963) parents expected to raise a socialite, teaching her French before English and sending her to Europe for art education. Ogilvie preferred independence and enrolled at Bryn Mawr College in Pennsylvania, where she discovered geology (Woods, 1964). At Bryn Mawr, she worked with Dr Florence Bascom, a pioneering mineralogist and petrologist who mentored the first cohort of female geology students in the United States (Aldrich, 1993). Graduating with a BA in 1900, Ogilivie began graduate work at the University of Chicago with T.C. Chamberlain and R.D. Salisbury, from whom she gained an appreciation for glacial geology. Returning to New York, she completed her PhD in 1903 at Columbia University (Ogilvie, 1905) and was appointed lecturer at Barnard College, a women's college founded in 1889 after Columbia refused to admit women.

While her first interest was petrology, Ogilvie recognized that if she wanted to teach graduate students (across the street) at Columbia, she would need to develop an area of expertise in which Columbia was deficient. She looked to glacial geology, where her work included analysis of glacial landforms in the Champlain Lake Valley and elsewhere in the Adirondack Mountains (Ogilvie, 1902) and field studies of the effect of debris cover on alpine glaciers (Ogilvie, 1904). She went on to teach successful and popular courses on glacial geology for many years.

The First World War brought another change in course to Ogilvie's career, as she became a leader in the US federal 'Food Will Win the War' campaign. Associate Professor of Geology by that time, she worked with the Dean of Barnard College to found the Women's Agricultural Camp in
Bedford, New York. The goal of the program was to recruit young women to farming in order to fill a growing labor shortage. The program was successful and Ogilvie went on to organize the Women's Land Army of America. Twenty thousand young women went to work on farms between 1917 and 1919 as part of the war effort. Ogilivie maintained her interest in agricultural science after the war and, while she continued teaching and mentoring students at Barnard, her attention was divided between geology and new administrative and research interests in agriculture. Her last publication, the abstract of a talk given to the New York Academy of Sciences in 1916, involved field observations of till sheets in the midwestern United States and their interpretation with respect to the number of glacial ages recorded by these deposits (Ogilvie, 1916).

\subsubsection{Ebba Hult De Geer}

Ebba Hult (1882-1969) followed a pattern well established for female scientists of the 19th century: private assistant to a male family member (Schiebinger, 1991, p. 260-261). Hult met Professor Gerard De Geer (1858-1943) in 1907 while a student in his class at Stockholm University. Swedish universities had opened to women in 1873, as part of a national response to the large number of unmarried and widowed women who needed employment (Elgqvist-Saltzman, 1998). De Geer proposed marriage, together with a job offer, while Hult was still a student. She agreed, suggesting a 5 year plan that included completion of her academic degree, and the two were married in 1908 (Bergwik, 2009). Hult De Geer's work as assistant to the professor continued until his death 35 years later, but the degree was never completed.

Ebba Hult De Geer's marriage allowed her to conduct scientific research that might otherwise have been beyond her reach (Bergwik, 2009). Working together with students in their Stockholm University laboratory, the De Geers established that the varved clays deposited in glacial lakes at the former margins of the Scandinavian ice sheet were geochronometers, with which paleoclimate might be investigated (De Geer, 1912, 1934; Hult De Geer and Wadell, 1928). The late-Quaternary Swedish timescale they produced was more precise and accurate than any other of its time. Gerard and Ebba recognized the importance of identifying global patterns in climate variability and made trips to examine varved deposits around the world. Hult De Geer continued to improve the Swedish geologic timescale after her husband's death (Hult De Geer, 1954) and published her own novel work, but while Gerard De Geer is lauded in the history of geochronology, Ebba Hult De Geer's contributions are seldom mentioned.

\subsection{Innovation}

\subsubsection{Dame Kathleen Lonsdale, DBE FRS}

'The crystalline structure of ice' was the subject of the first paper authored by a woman to appear in an IGS publication (Owston and Lonsdale, 1948). Owston and Lonsdale used diffraction patterns generated by bombarding ice at different temperatures with X-rays to study its structure. In the Journal, they proposed that the hydrogen atoms in ice crystals vibrate continuously in the space between oxygen atom pairs and that the frequency of the vibration depends on temperature. X-ray crystallographer Kathleen Lonsdale (1903-71; Fig. 3) is perhaps most widely recognized for her experimental work on benzene (Lonsdale, 1929) and careful calculations of 


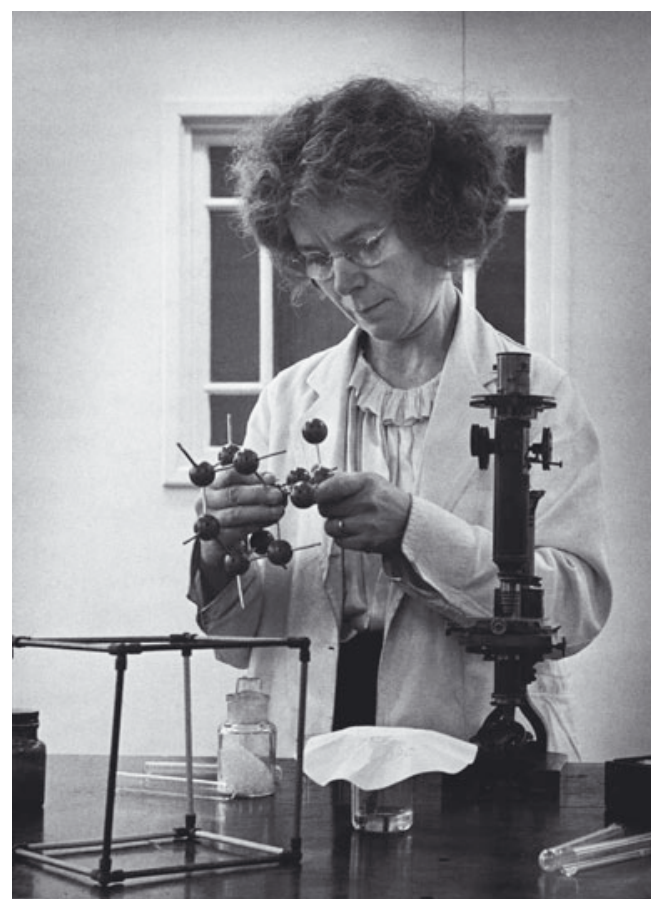

Fig. 3. Dame Kathleen Lonsdale, 1948. (C) Corbis

crystal space groups, but her contributions to crystallography and crystal dynamics spanned a range of topics, including water ice (Owston and Lonsdale, 1948; Lonsdale, 1958).

Kathleen Yardley excelled at school, but her interests and abilities exceeded the offerings at the girls' school in Ilford, England, to which Jessie Yardley had moved her six children to escape unrest in Ireland. Yardley was allowed in her last 2 years to attend courses at the County High School for Boys where physics, chemistry and advanced mathematics were taught. Having earned a scholarship, she entered the University of London Bedford College for Women at age 16 and went on to earn the highest score in the 1922 BSc (Hons) physics examination. Her performance on the exam so impressed crystallographer Sir William H. Bragg that he invited her to join his research group at the University College of London. A year later the group moved to London's Royal Institution (RI). Yardley remained at the RI until 1927, when she married Thomas Lonsdale, a textile chemist. Untypically for his time, Lonsdale assumed that his wife would continue with her scientific work after marriage (Hodgkins, 1975).

The Lonsdales followed Thomas's career to Leeds, where Kathleen found laboratory space in the university Department of Physics. She conducted her groundbreaking work on benzene there, using equipment she assembled for that purpose. The first of their three children was born in 1929 and the family returned to London soon thereafter, again following Thomas's employment. The return to London interrupted Kathleen's experimental work, but she adapted to the changed circumstances, turning to the numerous calculations required to determine crystal structures from $X$ ray images (Astbury and Yardley, 1924). This work was facilitated by small grants arranged by William Bragg, at Lonsdale's suggestion, for the purpose of hiring a housekeeper (Lonsdale, 1970).

Soon after her marriage, Lonsdale applied for the 1851 Exhibition Fellowship, a prestigious research grant awarded by the British crown. In declining her application, the
Commissioners of the fellowship told her that 'they would be breaking the spirit of the regulations in awarding an exhibition to a married woman'. This reaction to Lonsdale's application reflects a common view in post-war societies, that women who had joined the labor force as part of the war effort should return to the home and 'traditional' gender roles (Baldwin, 2009). Lonsdale confronted similar attitudes to women in science throughout her career. In 1957 she helped draft a Royal Society report about the state of science education in British schools that, due to Lonsdale's persistence, recognized the pervasiveness of prejudices against women obtaining advanced science education. The report was suppressed by the President of the Royal Society (Baldwin, 2009).

Dame Kathleen Lonsdale's scientific career was long, successful and multidimensional. She was a vocal advocate for women in science, worked for prison reform in the UK, and, as a pacifist, was willing to go to jail (where she carried on some computations regarding anomalous reflections in X-ray patterns) for her beliefs. In 'Women scientists - why so few?' Lonsdale (1971) wrote about the challenges women face in confronting cultural norms:

She must go against all her early training and not care if she is regarded as a little peculiar. She must be willing to accept additional responsibility, even if she feels that she has more than enough. But above all, she must learn to concentrate in any available moment and not require ideal conditions in which to do so.

She asserted that for married women, a partner willing to take an equal share in household responsibilities was essential. Lonsdale benefited from having such a partner but also from her own ability to develop networks among her colleagues and adapt to changing circumstances as they arose.

\subsubsection{Eleanora Bliss Knopf}

Structural petrologist Eleanora Bliss Knopf (1883-1974) made an early appearance in the Journal of Glaciology, as ghostwriter for the posthumous publication of Max $\mathrm{H}$. Demorest's work on instantaneous recrystallization of glacier ice (Demorest, 1953; Knopf, 1953). Demorest's notes were given to Knopf by his widow, following his death in Greenland during the Second World War. Eleanora Bliss was a contemporary of Ida Ogilvie, under the mentorship of Florence Bascom at Bryn Mawr College (Aldrich, 1993). Bliss spent 5 years as curator of the college geological museum before beginning her doctoral work at the University of California, Berkeley. Completing her PhD at Bryn Mawr College in 1912, she joined the United States Geological Survey (USGS) as a geologic 'aide'. Bliss married fellow geologist Adolph Knopf in 1920 and followed him to Yale University, where she continued her work for the USGS on a contract basis and taught private courses. Her influential text on petrofabrics (Knopf and Ingerson, 1938) was written during this time. Following Adolph Knopf's retirement in 1951, the couple moved to California, where he was given a courtesy faculty appointment at Stanford University and Eleanora was appointed research associate. She continued with petrographic research until her death in 1974.

\subsubsection{Isobel Moira Dunbar, OC FRSC}

Moira Dunbar (1918-99) was a pioneer in Arctic sea-ice observation and the use of remotely sensed data for sea-ice research. Dunbar studied geography at Oxford University, 
earning a BA (Hons) in 1939 (St Anne's College) and completing her MA in 1948. Her career in sea-ice research began soon after she arrived in Canada on a visitor's permit in 1947. Learning that the federal government needed trained geographers, she applied and was assigned to the Joint Intelligence Bureau of Canada. Her first assignment was editing a book of Arctic terrain and sea-ice descriptions and photographs, written by two air force navigators (Greenaway and Colthorpe, 1948). From there she moved up to Scientific Staff Officer in the Arctic Research Section of the Defense Research Board of Canada.

Dunbar's interest in sea ice quickly exceeded the confines of photographs and offices and in 1954 she applied for a post on a Department of Transport icebreaker. Her request was turned down but she persisted, moving up the chain of command until in 1955 a deputy minister approved the posting. Dunbar commented about this, 'There were so many people against taking me up that the matter went right up to Deputy Minister level. However, he decided I was probably harmless' (The Herald, 1999). Better than harmless, Dunbar proved to be good company and continued to serve on icebreakers for many years. Recognizing the value in airborne observation, she reprised her role as a campaigner for access to a strictly male enterprise, eventually gaining a place on Royal Canadian Air Force operational flights into the High Arctic. She logged a total of 560 hours on the Argus ice patrol aircraft before retiring (Gold, 2002). A colleague reflected on her tenacity, 'You didn't want to be between where Moira was and where Moira wanted to be. She knew what she wanted to do and what she was doing' (personal communication from W. Weeks, 2010).

Throughout her career, Moira Dunbar was an innovator, developing new tools and methodologies for sea-ice research. Working with Keith Greenaway, she pioneered the use of airborne photography for sea-ice observation (Dunbar and Greenaway, 1956) and went on to investigate the use of radar remote sensing for sea-ice studies (Dunbar, 1975). Dunbar was a proponent of winter navigation in the Gulf of St Lawrence and worked to standardize sea-ice terminology (Dunbar and others, 1965). Recognizing the substantial contributions made by Russian scientists to seaice studies, she studied the language and qualified as a Russian linguist in 1958.

Moira Dunbar's creative talents extended far beyond the scientific laboratory. She performed with the Oxford University Drama Society, worked as a professional actor during the Second World War and wrote popular articles about the history of Arctic exploration. A passage from 'Man and ice: experience with the frozen ocean' captures both her sensibility and her wit:

The first people who really became familiar with the ice were, of course, the Inuit. They lived amid ice. They used it as a highway and as a platform to hunt from, and they did not try to fight it. It was only the Europeans who tried to force their way through the ice in order to get somewhere else. The Inuit did not want to be somewhere else; they were quite happy where they were.

(Dunbar, 1986)

\subsubsection{Jean M. Grove}

Jean Mary Clark (1927-2001) was born into a scientific family. Her mother, Mary (Johnson) Clark, was among the first female research chemists at the University of Cambridge, UK.
As a student at Newnham College, Cambridge, Mary Johnson placed above all the men in her cohort at the conclusion of the natural science courses in 1917, yet could not continue on because women were ineligible for higher degrees at Cambridge at that time (Rayner-Canham and Rayner-Canham, 2008, p. 233). She instead took a job as a research chemist, but resigned at the time of her marriage to a colleague. Mary and Leslie Clark's daughters, Jean and Margaret, grew up enjoying family mountaineering trips in Scotland and Norway, and both followed their mother's path to Newnham College.

Jean Clark completed her undergraduate work in geography in 1948 and continued on with research for her master's degree while working as assistant lecturer in geography at Bedford College, London. Founded in 1849, Bedford was the first women's college in the UK. While still an undergraduate, she joined the first of several research expeditions to Jotunheimen, Norway, with Vaughan Lewis and others from Cambridge. The team investigated many aspects of glacier activity in the region, producing papers on both glacial erosion (Clark, 1951) and glacier flow (Clark and Lewis, 1951). Fieldwork conducted in 1952 and 1953 on Veslskautbreen and Veslgjuvbreen formed the basis for her doctoral thesis, 'A study of the physiography of certain glaciers in Norway'. The PhD was awarded in 1956, 2 years after she married fellow geographer Dick Grove and the year after their first child was born. Five more children joined the family between 1956 and 1971 .

Jean Grove continued to conduct fieldwork in Norway and the Alps, but over time her attention turned to Holocene climate variability. Combining traditional approaches such as dendrochronology and ice-core analyses with innovative archival work, she assembled detailed records of glacier variations around the world and used these records to examine spatial variability in climate change. This research led to the widely-read text The Little Ice Age (Grove, 1988). A second, more expansive compilation of her research, in progress at the time of her death, was published in 2004 (Grove, 2004).

Grove was appointed lecturer and director of studies at Girton College, Cambridge, in 1953 and was elected to Fellowship in the College in 1960 (H.D. Allen, http:// www.quaternary.group.cam.ac.uk/history/others/Grove. $\mathrm{html})$. She remained director of studies until her retirement in 1994 and was very involved in student life at Girton throughout, encouraging students to engage in fieldwork and improving access for students from state schools. Bringing her children to the mountains, as was her own childhood experience, allowed Grove to continue fieldwork in the midst of a growing family and considerable administrative responsibilities at Girton. But it was also during these years that she turned to historical studies of glacier variations, an activity that was more adaptable to life with a large family. Grove also benefited from a supportive husband who shared childcare responsibilities, and from the labor of hired au pairs (Goudie, 2001, p.283-287; Maddrell, 2009).

\subsubsection{Cuchlaine A.M. King}

Born into an academic family, Cuchlaine King (b. 1922; Fig. 4) and her sister Margaret both earned BAs in Geography at Cambridge, in 1943 and 1942 respectively. Both followed their father, the eminent geologist William B.R. King, OBE MC FRS, into war service. Cuchlaine King joined the 


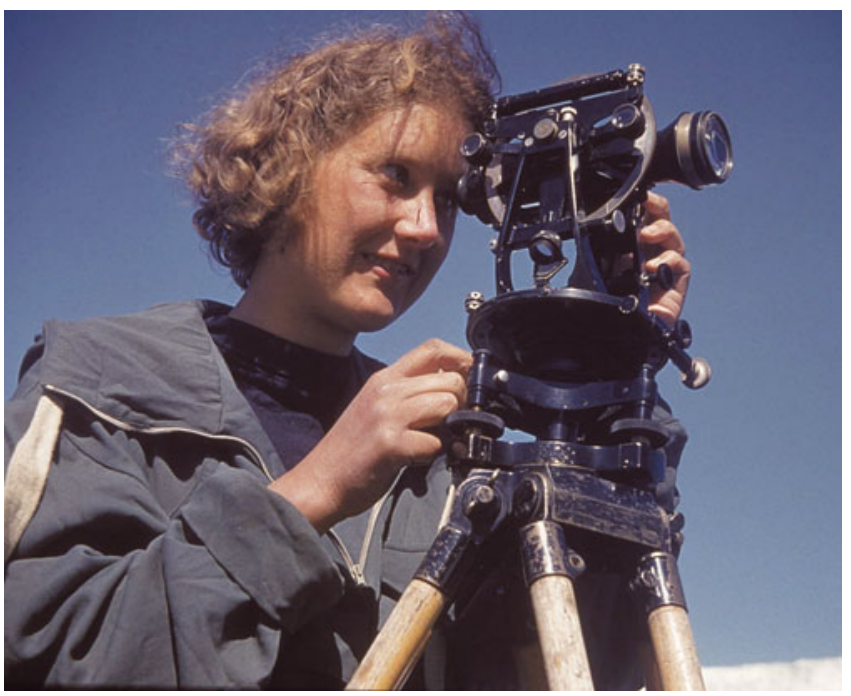

Fig. 4. Cuchlaine King surveying on Morsájökull, southeast Iceland, during the University of Nottingham expedition, July 1953. Photo by Jack D. Ives.

Women's Royal Naval Service and went on to work in the meteorological services and as a surveyor with Cambridge professor Frank Debenham. Many women were recruited into both teaching and military service as geographers during the Second World War, but for most their jobs ended at the conclusion of the war (Maddrell, 2008).

King continued in geography at Cambridge after the war, completing her doctoral dissertation on the movement of sand on beaches in 1949 (King and Williams, 1949). Her work with Professor William Williams synthesized field observations and laboratory experiments in a quantitative style that moved the discipline forward. In his enthusiastic review of her text Beaches and coasts, Balchin (1960) wrote that the book offered 'a new and unique approach with a mathematical and quantitative treatment'. King continued to study coastal processes throughout her career but also investigated glacial processes in landscape evolution, an interest she developed at Cambridge while working with Debenham and Vaughan Lewis.

Fieldwork was essential to King's research and, like Moira Dunbar in Canada, she set precedents in the Arctic for other women to follow. Her first research trips to Iceland with Jack Ives came not by invitation but at her suggestion (Ives and King, 1954, 1955; King and Ives, 1955, 1956). When King inquired, Ives replied that he had never thought of including women, but responded positively, suggesting that some other women come along for 'company' (Maddrell, 2009, p. 239). King participated in the Cambridge expeditions to Austerdalsbreen, a small Norwegian glacier where dozens of students were trained in projects that laid the foundation for post-war glaciological research in the UK (Nye, 1997). She worked again with Ives on Baffin Island in the mid-1960s (where accommodation away from the men's quarters was required by the US Air Force), and led many field projects of her own design.

Dr King joined the Faculty of Geography at University College, Nottingham, in 1951, where she remained until her retirement. She proceeded up the ranks, with promotion from assistant lecturer to lecturer in 1953, to reader in 1962 and finally professor in 1969. In an interview about the course of her career at Nottingham, King recalled the promotion to professor: 'I remember Professor Edwards saying that he [a male colleague] should have the professorship first although he thought I probably deserved it.' When asked why she had been passed over, King suggested 'perhaps they didn't want a lady professor' (Maddrell, 2009, p. 238) but did not bear any ill will about it, noting that postponing administrative duties allowed more time for research. King also reflected that never having married allowed her to devote more energy to research and teaching than might otherwise have been possible (Sack, 2004).

\subsubsection{Laura Levi}

Cuchlaine King and Moira Dunbar were together responsible for all but one of the first-authored research papers by women in the first two decades of the Journal of Glaciology. The one exception is 'Experimental study of non-basal dislocations in ice crystals' by Levi and others (1965). Dr Laura Levi published 68 scientific papers, many on ice in the atmosphere, during her long and productive career as a crystallographer and atmospheric physicist.

Laura Levi (1915-2003) was born in Parma, Italy, into a family of scholars. Her father, Beppo (1875-1961), and his brother Eugenio were both distinguished mathematicians, and Beppo's brother Decio was an engineer. Both Eugenio and Decio were killed in the First World War. Beppo Levi is most widely known for his eponymous lemma regarding the exchange of integration and limits using the Lebesgue integral but should also be remembered for his work on algebraic surfaces, among other contributions. The family moved in 1928, when Professor Levi accepted an appointment in the Faculty of Mathematics at the University of Bologna. Laura Levi studied physics there, completing her $\mathrm{PhD}$, 'Ferroelectric properties of Rochelle salt', in 1938. This was the same year she lost her Italian citizenship.

Neither the Levi family's anti-fascist politics nor their ethnicity created a problem until Mussolini's 1938 Manifesto on race. With that, Jewish Italian scholars lost their jobs, and most sought refuge abroad. Professional relationships Beppo Levi had developed while managing the Bolletino della Unione Matematica Italiana proved important at this juncture. An invitation to become the founding director of the Institute of Mathematics at the National University in Rosario, Argentina, allowed the family to follow a well-worn emigrant trail from Italy to Argentina in 1939 (Levi, 1998). The influx of European scholars between the world wars invigorated an Argentine university system that, in the decades ahead, would become a field upon which political battles were waged (Street, 1981; Stacco, 2002; Ortiz, 2003).

Laura Levi's early research carried forward the themes from her student years in Italy. Her first published work, a study at the Arapey hot springs in Uruguay, was completed while an assistant in the University of Montevideo Institute of Physics, an appointment she held from 1942 to 1946. Levi returned to Argentina in 1947, and for the next 10 years investigated ferromagnetic materials and other topics in crystallography in the Department of Physics at the National University of La Plata and with the Institute for Scientific and Technological Research for Defense (Levi, 1956). Despite ongoing political upheaval, often accompanied by restructuring of the education system (Street, 1981), the University of Buenos Aires (UBA) grew and founded new research groups, including an Institute of Atmospheric Physics. Laura Levi joined the multidisciplinary group within the 
Faculty of Exact and Natural Sciences in 1957. Among their charges was the investigation of cloud physics and hail, a theme in which Levi found a place for her interest in crystallography (Jaccard and Levi, 1961; Levi and others, 1965; Arias and others, 1966).

Levi's ice crystal studies served her well in 1966 when, in the aftermath of the coup led by General Juan Carlos Onganía, she was able to obtain an invitation to the Hokkaido University Institute of Low Temperature Science, Japan. The 'Revolución Argentina' instituted a number of reforms, including suspension, on 28 July 1966, of the University Reform of 1918 . The Reform of 1918, initiated by students at the National University of Córdoba (UNC), granted autonomous governance to the university system and led to modernization of science curricula. The Faculty of Exact and Natural Sciences at UBA voted to reject Onganía's order, and on 29 July federal police swept students and faculty from the Faculty of Science and other university buildings. The police employed considerable violence in what became known as 'la Noche de los Bastones Largos' (the Night of the Long Batons) and raids were conducted at universities throughout the country. In the months that followed, the president of UBA, deans and professors resigned their positions and sought refuge abroad, Laura Levi among them.

Levi continued her studies on the electrical properties of ice, while also investigating crystal growth in the atmosphere, during her years away from Argentina, first at Hokkaido and then from 1967 to 1968 at the Swiss Federal Institute for Snow and Avalanche Research in Davos. Levi had earlier collaborated with Claude Jaccard on the segregation of impurities in ice crystals, a topic of considerable interest in the context of crystal growth in the atmosphere (Jaccard and Levi, 1961). At Davos, Levi pioneered the use of wind-tunnel experiments to study hail formation under varying atmospheric conditions (Levi and Aufdermaur, 1969, 1970). The experimental work was later expanded to include numerical modeling and comparison between laboratory and natural hail samples (Levi and others, 1970).

Returning to Argentina in 1969, Levi held appointments at several institutes, including the National Atomic Energy Commission, where she continued her crystallographic work on accreted ice and other materials (Levi, 1970, 1973). Levi tackled a new challenge in 1973, the creation of an Atmospheric Physics program in the Faculty of Mathematics, Astronomy and Physics at UNC (Weissmann and others, 2003). Founded in 1613 (originally as the University of Tucumán), UNC was Argentina's first university and is among the oldest universities in the Americas. The group maintained an important foothold for applied physics during a time when Argentine universities were held suspect by the government and scientific research was not recognized as contributing to the national economic endeavor. From the 1980s forward, Levi's hail studies diversified to include not only experimental and analytical work but the development of hail parameterizations for meteorological models and validation of those models using severe storm observations. She remained actively engaged in glaciological research into her eighties; her last e-mail to a scientific collaborator was sent only a few days before her death.

In her early twenties, Laura Levi escaped European fascism only to arrive at the advent of political turmoil in Argentina. Over the next six decades, Levi never gave up on science, or on its place in the human endeavor and the development of Argentina. From the 1960s to the end of the 1980s, Argentine universities and scientific institutes were subject to frequent political purges (Wade, 1976), conditions that make Levi's contributions to glaciology all the more remarkable. In addition to research, she had a keen interest in photography, exhibiting her work in public shows, and in philosophy, participating in philosophical study groups and always ready for a conversation about art, literature, politics or science. Students and colleagues remember Levi for her dedication to science and to the community in which she lived (Weissmann and others, 2003).

\subsubsection{Hilda Richardson}

As did many young women of her generation, Hilda Bentley (1924-2000) went to work for the war effort as soon as she graduated from secondary school. At the end of the Second World War she left the UK Meteorological Office and entered Newnham College, Cambridge, to study geography. A student of Vaughan Lewis and Gordon Manley, she participated in the Cambridge Austerdalsbreen expeditions (Nye, 1997) and formed lifelong friendships with other snow and ice enthusiasts. During this time, the dormant Association for the Study of Snow and Ice at Cambridge was revived as the British Glaciological Society (BGS). After completing her MA in Geography in 1948, Hilda Bentley went to work for the Unilever company in their market research division at Port Sunlight, near Liverpool (Ommanney, 2001; personal communication from A. Thomson, 2010). Hilda married Eric Richardson, a fellow Cambridge geographer, in September 1950.

The BGS and its flagship publication the Journal of Glaciology were growing steadily by 1950 and needed both a permanent home and an organizational leader. The home was found at the Scott Polar Research Institute (SPRI) in Cambridge and the decision was made to create a full-time position of Secretary to the BGS. The first person hired to the position resigned after a year and Hilda Richardson was hired in late 1953 as the Society's only employee (Wood, 1986, p. 85-86). Reflecting changes in the Society during Richardson's tenure, the name would change to Glaciological Society in 1962 and International Glaciological Society in 1971. Her position title was amended to Secretary General in 1977.

At the time of Richardson's hiring, the BGS leadership had begun to consider its role in supporting glaciological research during the upcoming International Geophysical Year (IGY, 1957-58). IGY activities raised the profile of glaciological research in the international scientific community, and Richardson began a series of careful conversations regarding internationalization of the BGS. A firm believer in change when change was needed, Richardson listened to her constituent community and moved forward as a strong advocate for the Society's role as an international leader and facilitator of scholarly exchanges. She carried those standards throughout her tenure as Secretary General.

The Society's role as an intellectual hub for the glaciological community matured under Hilda Richardson's stewardship as Secretary General. She defined the position and its responsibilities, and in so doing moved the Society forward. International Symposia, today a hallmark of the Society, took shape under her guidance. She extended the embrace of Society membership and participation in its activities to all regions of the world and encouraged diversification of the Society's management. As soon as 


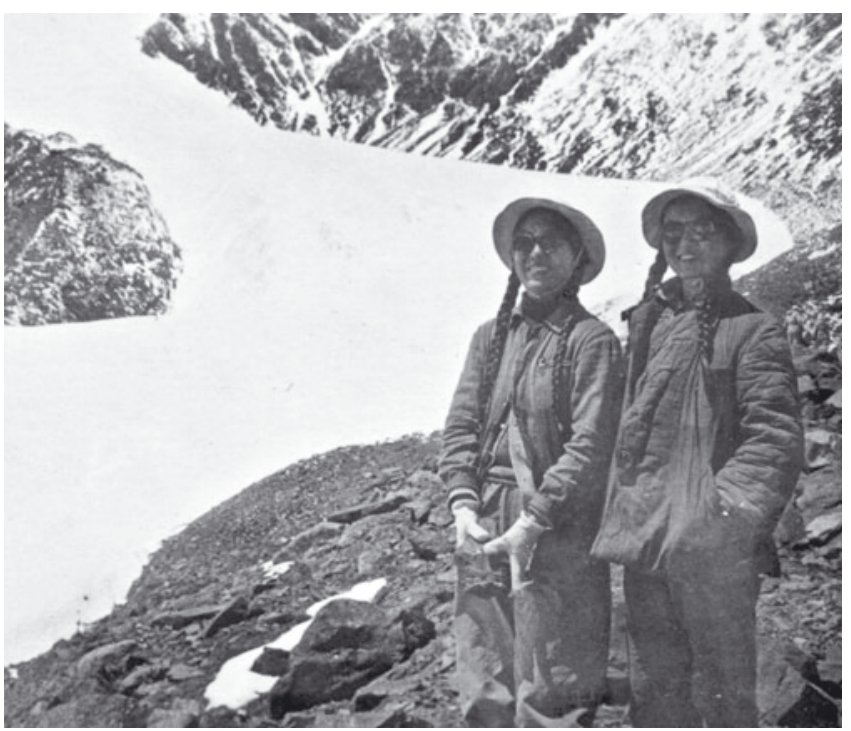

Fig. 5. Lai Zuming (left) and Yang Zhenniang (right) at Ürümqi glacier No. 1, Tien Shan, China, in 1961.

her position became full-time, she joined Soroptimist International (SI), a professional women's organization. She was able to leverage travel and personal connections established through SI and the IGS for the betterment of both organizations. The Richardson Medal for outstanding service to the IGS and to glaciology was created upon her retirement in 1993, as a testament to her fundamental contributions to the discipline of glaciology.

\subsubsection{Yang Zhenniang}

Chinese glaciological research began in earnest in 1958, with the establishment of a glacier investigation base in Lanzhou, Gansu Province. The Chinese Academy of Sciences approved the creation of a Glaciology and Geocryology Division within its Institute of Geography in 1962, and in 1965 this became the Lanzhou Institute of Glaciology, Geocryology and Desert Research. The institute grew under the guidance of Professor Shi Yafeng, as a few new university graduates were assigned research positions each year. Glaciological research activity slowed between 1966 and 1976 (Zhang and Yang, 2008), as the national scientific effort was redirected toward solving practical problems. Following the Cultural Revolution, the Lanzhou Institute divided into two parts, one for Glaciology and Geocryology and the other for Desert Research. Four women, Yang Zhenniang and Lai Zuming, both of whom specialized in glacio-hydrology, Wu Xiaoling, who specialized in ice-core studies, and Zhang Shuanying, who specialized in remote sensing, were among the pioneers of glaciological research in China. Women in the early generations of Chinese glaciologists did not encounter the educational prejudices common for women in the West, but did face the same challenges of balancing research and domestic responsibilities.

Yang Zhenniang (b. 1936) was born to a Chinese traditional-medicine family who had lived for many generations in Indonesia. After 1949, Yang's older and younger brothers returned to China, where there were new opportunities and a chance to help shape the country's future. Encouraged by her father, Yang followed her brothers' path to Nanjing in 1953, where she completed her secondary school education. Her first interest was, in the family tradition, medicine, but her university placement exam scores led to the East China Technical University of Water Resources, where she studied land hydrology from 1955 to 1960.

Upon completion of her degree in hydrology, Yang was assigned to the National Department of Hydrology and Power in Beijing, where she worked for a year before being reassigned to the new glacier research group in Lanzhou. Her first project at Lanzhou involved flood prediction for glacier and snow-fed streams in the Tien Shan. The work was reported in both the Chinese scientific literature and the popular news. Following this start, she went on to specialize in glacier hydrology. As glacier research slowed during the Cultural Revolution, Yang developed methods for studying and preventing debris flows and worked on the institute's farm, where she was often assigned to provide day care for other workers' children.

After the Cultural Revolution, Yang returned to glaciological studies and broadened her research program to include other cold region processes. In 1984 she founded a cold region hydrology program in the Qilian Shan, along the border between Qinghai and Gansu Provinces in northern China. The many small streams flowing northeast from the Qilian Shan support irrigated agriculture in the lowlands to the north and are thus an important regional resource. Yang assembled and led a group of younger scientists in the arduous high-elevation ( $\sim 4000 \mathrm{~m}$ and higher) conditions. Together they built and worked at China's first cold region hydrological station. Yang continued to lead annual field teams to the station until her retirement in 1996.

As a founding member of the Lanzhou Institute, Yang played an important role in shaping glacier research in China. She published three books and 70 papers over her nearly 40 year career (Yang, 1982; Yang and others, 2000; Yang and Zeng, 2001). In her first book, Glacier water resources in China, Yang (1991) compiled and analyzed the prior 30 years' work on glacier hydrology in China. Written in response to a request from the National Department of Hydrology and Power, the book was the first comprehensive survey of its kind, and Yang won the National Science and Technology Progress Second Award in recognition of the accomplishment. Today she cites this as her most satisfying research project (personal communication from Yang Zhenniang, 2010). Yang also served as the Lanzhou people's representative, member of the Chinese People's Political Consultative Conference (CPPCC), and member of the CPPCC Standing Committee in the Gansu provincial government. Writing in 2003, Shi Yafeng cited Yang's dedication to research, innovative spirit and ability to overcome any challenge that stood in her way as an example for future generations (Shi, 2003).

\subsubsection{Lai Zuming}

Lai Zuming (b. 1937) grew up in DeYang, Sichuan Province, China. Lai's family encouraged her academic interests and preparation for university entrance exams. In 1956 she matriculated at Chengdu University of Technology to study land hydrology. Graduating in 1960, she was assigned to work with the new Lanzhou glacier research group. Lai specialized in glacier hydrology, at first with an emphasis on flood prediction on the north slope of the Tien Shan and the Ürümqi river (Fig. 5). During the Cultural Revolution, Lai was assigned to desalination research, for which she used mathematical models to study optimization of reverse 
osmosis methods. She also collaborated with Yang and Wu on debris flow studies during this time.

The importance of glacier meltwater to arid region hydrology was a founding interest at the Lanzhou Institute, and when Lai returned to glaciology after the Cultural Revolution her work emphasized the effect of climate change in meltwater production. In the early 1980s she led the Tien Shan component of the first Chinese glacier inventory project, during which more than 3000 glaciers were cataloged. Her work in later years would build upon this foundation. Lai was among the first researchers at the Lanzhou Institute to incorporate computational modeling into their work, using hydrologic models to evaluate meltwater production under changing climate conditions (Lai, 1987; Lai and Ye, 1991).

\subsubsection{Wu Xiaoling}

Growing up in Beijing, Wu Xiaoling (b. 1934) followed the same track as most city girls, completing the full 12 years of primary and secondary school before taking the university placement exam. In 1954, she was assigned to study geology at Moscow State University. Completing her studies in 1959, Wu was assigned to work at the Beijing Geological Institute, where she participated in power station and railroad design projects. She was transferred to the Lanzhou Institute in 1965 to begin new projects with Professor Shi Yafeng. The Cultural Revolution began soon thereafter and $\mathrm{Wu}$ joined the debris flow research group that formed at Lanzhou.

Wu returned to glacier research after the Cultural Revolution. Initially, her work followed a long-standing interest at the Lanzhou Institute, water resources. Wu joined the institute's Qilian Shan research in the early 1980s, using hydrogen isotopes to investigate groundwater recharge by snowmelt in the Lenglongling district of the Qilian Shan $(\mathrm{Wu}, 2007)$. Wu pioneered ice-core studies on Chinese glaciers, assembling a research group at Lanzhou for that purpose. Fieldwork began on the Dunde ice cap in 1984, and the first boreholes reached bedrock in 1986 (Thompson and others, 1988; Wu and Thompson, 1988). These were the first glacier boreholes drilled to bedrock in China.

\subsubsection{Almut Iken}

Almut Iken (b. 1933) began her secondary school studies as her divided homeland began to rebuild itself in the aftermath of World War II. As German scientists started to reconstruct their research programs, West German society was reconstructing itself as well. Political and social leaders rejected the biological essentialism of the Third Reich, but in promoting women's right to equal status in society the emphasis was 'equality in difference', that is, a woman's right was to a private domestic sphere, free from interference by the state (Höhn, 1993; Moeller, 1998). The underlying view of women's role in society thus changed little and, as before the war, there was scant room for women in the new German scientific enterprise. Indeed, the rate of women earning PhDs in mathematics and the natural sciences was larger in the 1920s than at any time since (Costas, 2002).

Almut Iken's interest in physics grew as she progressed through secondary school and this motivated her toward science and math courses, and toward preparation for the teaching licensure exam. As elsewhere, teaching was recommended to German women who sought professional work outside the home (along with social work and other 'helping' occupations). Upon passing the exam, Iken began what she expected to be a career teaching. Vacations spent hiking in the Alps, Norway and Swedish Lappland sparked an interest in glaciers, and Iken set her sights on visiting the polar regions.

After 7 years teaching secondary school and observing glaciers while on holiday, Iken wrote a letter to Professor Richard Goldthwait at The Ohio State University, asking how she might find a 2 year job working in the Arctic or Antarctic. She received in reply an application form for a field assistantship in Antarctica. Unfortunately, Goldthwait was unfamiliar with German names and had assumed that Almut was male. Antarctic fieldwork was at that time, 1967, out of reach for women. Goldthwait forwarded her letter to Professor Colin Bull, an advocate for women in field science. Bull replied with detailed advice about how Iken could best prepare herself for glacier field studies. She followed his suggestion and enrolled in a training course in northern Sweden, where she learned surveying and stream observation methods. With the appropriate training on her resumé, Iken applied for work with field programs at McGill University in Montreal and the University of Alaska in Fairbanks. Professor Fritz Müller at McGill replied first and Iken prepared to join the Jacobson-McGill research program on Axel Heiberg Island in the Canadian Arctic. Her plan was to return after 2 years to her teaching position in Germany.

Iken's project on Axel Heiberg Island included resurveys of velocity markers and ablation measurements on White Glacier. Professor Müller suggested a period of short-term surveys, at intervals of a few hours. Iken carried out the surveys and found considerable variation in glacier velocity on a range of timescales, including a diurnal variation that appeared to be related to variations in stream discharge. The observations set Iken thinking about water pressure at the glacier base and pathways for water through the glacier system. Working with materials at hand on the island, she constructed an electrical resistance meter using two electrodes, a cable, and plastic hose as a protective casing for the instrument. She lowered the tube into a moulin, it soon became stuck and she started planning a better scheme for the following season (Iken, 1972). Clearly, Iken was destined to become a glaciologist.

Returning to Montreal in the fall, Iken discovered that both doctoral students and field assistants earned the same wage. With Müller's endorsement, she abandoned the plan to return to secondary school teaching and entered the graduate program at McGill. She devoted her energy to studying the glaciological literature and preparing for a doctoral thesis on velocity variations on White Glacier, a theme through which she would go on to make fundamental contributions to science. The student salary was small, but the reward of frugal living was the opportunity to work in the Arctic and to study with McGill professors Müller, John Elson and John Jonas, all of whom encouraged her to pursue both her field and theoretical interests in glaciology. When Müller moved to the Swiss Federal Institute of Technology (ETH) in Zürich, he invited a group of students to join him, Iken among them. She completed her PhD at ETH (Iken, 1974) and took up a research position of her own.

Over the following decades, Iken expanded her field program to investigate glacier sliding and ice deformation in many settings and developed mathematical models of these processes. Her work was both innovative and influential 

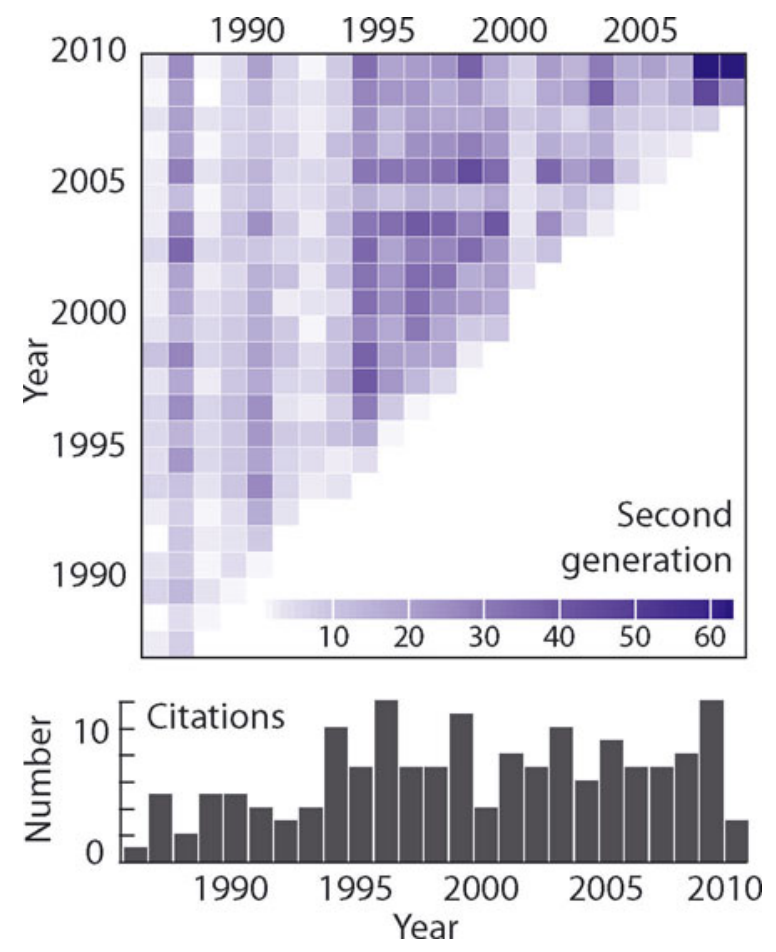

Fig. 6. The deep influence of Iken's work on glacier sliding is demonstrated by the longevity and intensity of citations of a hallmark Journal of Glaciology paper. Top: Color map of 4108 'second-generation' citations of papers citing Iken and Bindschadler (1986). Bottom: One hundred and sixty-four 'firstgeneration' citations of the same paper by year. Citations of these papers are mapped in the top panel. Citation database downloaded from the Web of Science, August 2010.

(Iken, 1981; Iken and Bindschadler, 1986; Fig. 6). Her work in Greenland (Fig. 7) fundamentally changed the understanding of Arctic glaciers, including the discovery of a thick layer of temperate ice at depth and the recognition that deformation within that layer was primarily responsible for the fast flow of the glacier (Iken and others, 1993; Funk and others, 1994; Lüthi and others, 2002).

Reflecting on her career as a glaciologist, Iken emphasizes the importance of early opportunities to participate in fieldwork. Prior to Axel Heiberg Island, Iken worked at the Arctic Institute of North America's Kluane Lake station in the Yukon, among a diverse group of scientists and students. One day, Walter Wood, a founding member of the institute, asked Iken if she wouldn't mind interrupting her (hutpainting) project to go for a reconnaissance flight with him. Flying over the surging Steele Glacier and other glaciers in the St Elias Range, she saw for the first time alpine glaciation writ large. Later that season, she was invited to join George Rigsby and Sam Collins on a surveying trip to Fox (now Rusty) Glacier as part of a project established in anticipation of a surge. She practiced her surveying skills, discussed trigonometry, learned the proper method for cooking dry spaghetti and marveled at the wilderness around her:

One night, when I stepped out of my tent and looked to the shining, white mountains around, thinking about the happy life I experienced, I wondered whether all this was real - or just a dream.

(personal communication from A. Iken, 2010)

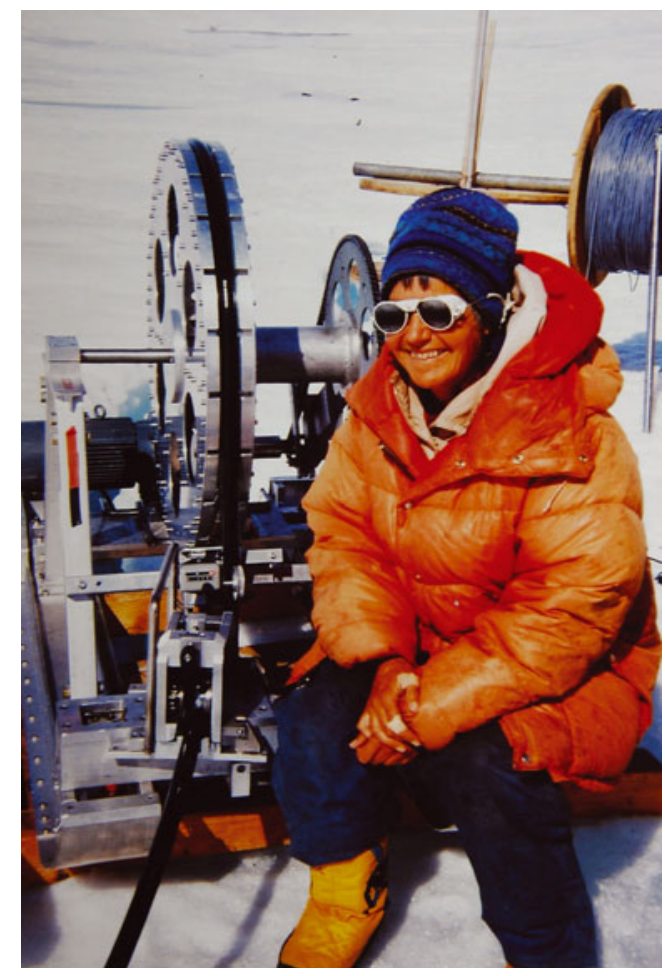

Fig. 7. Almut Iken on Jakobshavn Isbræ, West Greenland, in 1990 with hot-water drilling equipment.

\subsubsection{Elizabeth M. Morris}

Like many others profiled here, Elizabeth Morris (b. 1946; Fig. 8) grew up in an environment where education was valued and a university education was expected. At school, she performed well in the humanities and the sciences, but her parents, both teachers of English, encouraged Morris to prepare for university studies in the sciences. This advice was a good fit for an academically minded girl with an interest in glaciated landscapes, first sparked by a televised movie about the Matterhorn. Arriving at the University of Bristol to study physics, Morris discovered that contrary to her parents' sensibility, it was possible to pursue both academic studies and sport, and the seed of her career in glaciology began to grow.

Elizabeth Morris completed her BSc in Physics at Bristol and continued on under the supervision of John Nye, completing her $\mathrm{PhD}$, 'The sliding of ice over rock and other substances', in 1972. Fewer than $5 \%$ of the student cohort were women at that time. Following her interest in glacial environments, she applied immediately for a post with BAS and was turned down, application unread. The rationale was simple: BAS facilities were of 'expeditionary type' and thus unsuited to women. Applying for a post at SPRI, Morris received a similar response: there was no job for which she could be considered because all involved fieldwork in the Antarctic. Undeterred from her interest in polar glaciology, Morris moved to the University of East Anglia, where her theoretical and experimental work on regelation under realistic conditions (Morris, 1976) found a good fit with Geoffrey Boulton's interest in subglacial till processes.

Recognizing the cultural challenges to her progress in field-based glaciology, Morris developed strategies to work around the obstacles. Taking a post at the Institute of Hydrology $(\mathrm{IH}$, now the Centre for Ecology and Hydrology), a research center parallel to BAS in its institutional structure, 
she brought snow studies to the institute and worked her way up the ranks with the support of the institute's founder, Jim McCulloch (Morris and Woolhiser, 1980; Morris, 1981; Morris and Thomas, 1985). When Charles Swithinbank retired as Head of the Earth Sciences Division at BAS, Morris, by then at the appropriate rank and recently put forward for a merit promotion, applied for the open position. She was hired in 1986 and in 1987 became the first woman to join a BAS field team, working with Julian Paren and JeanLouis Tison on the George VI Ice Shelf.

In the years since her move to BAS, Morris has led field parties in both the Antarctic and Arctic, investigating the physics of snow and the mass balance of polar ice masses (Morris, 1999; Hawley and others, 2008). While Morris's enthusiasm for polar travel and the element of the unknown inherent to field science is unrivaled, her theoretical contributions to glaciology are considerable, and indeed the combination of the two is the hallmark of her work (Morris and Cooper, 2003; Hawley and Morris, 2006; Morris, 2008). She was awarded the Polar Medal in 2003 for her contributions to science in the UK.

Throughout her career, Elizabeth Morris has maintained the careful focus on research about which Kathleen Lonsdale wrote in 1971. She began her postdoctoral work at a time when open misogyny was falling out of fashion and administrators understood the political importance of hiring female graduates (Hammond, 1992). She nevertheless faced considerable prejudice, both institutional and personal, but like Moira Dunbar was able to put it aside and continue on toward where she wanted to go. Reflecting on her progress through the ranks and on her female colleagues who did not make it so far, Morris is candid:

There were an awful lot of women around who were trying to do the same thing I was trying to do. You could be shot down at any time but, by chance, I wasn't. I wasn't shot down as I rushed out of the trenches.

(personal communication from E.M. Morris, 2010)

\subsubsection{Kumiko Goto-Azuma}

When the young Kumiko Goto (b. 1958) attended a public lecture on ice crystals given by Professor Akira Higashi, 15 out of every 100 university students in Japan were women (Ogawa, 2006). Two or three of those 15 would have been studying science, most likely biology or chemistry. The place to find women on campus was in humanities departments (where about $60 \%$ of majors were women) and education and health departments (about 50\% and 35\% respectively). Indeed, as a high-school student, Goto was counseled by a teacher, 'there is no way that a woman can be a professional scientist. You should choose pharmacy so that you can sell medicine at a drug store even after you get married' (personal communication from K. Goto-Azuma, 2010). This was common advice at the time and, like the other women discussed here, Goto struck out on a nearly uncharted path when she decided to turn her childhood love of snow into a scientific career.

Inspired by Professor Higashi's lecture, Kumiko Goto applied to study in the Department of Applied Physics at Hokkaido, where his research team was using X-ray diffraction and other techniques to study ice crystal structure and deformation (Hondoh and others, 1983; Goto and others, 1986). Goto completed her undergraduate degree in 1981 and continued on for MS and PhD work, despite

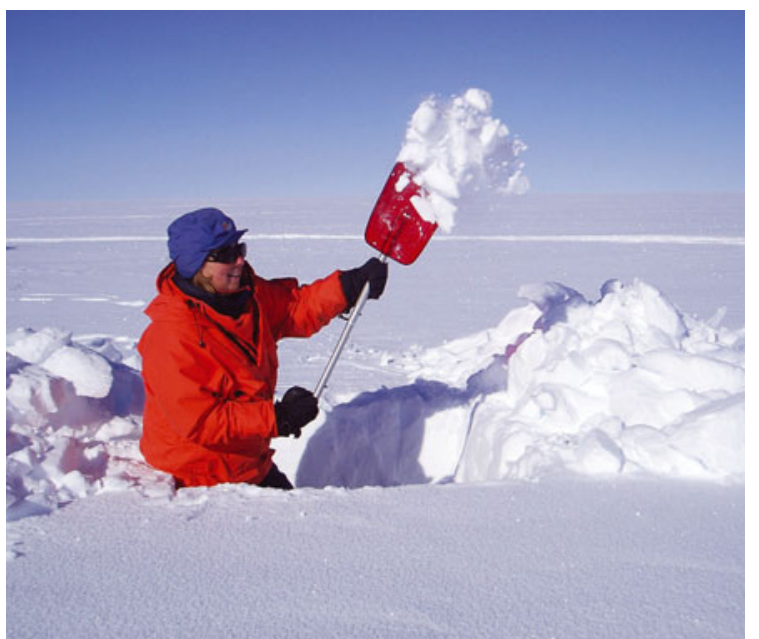

Fig. 8. Liz Morris engaging in a favorite pastime during the Greenland spring, 2004.

having been again advised that women should not consider careers as research scientists. She completed her PhD on lattice defects in 1986, married fellow glaciologist Nobuhiko Azuma and began the first of two postdoctoral appointments with Professor Chester Langway at the State University of New York (SUNY) in Buffalo that year. The introduction to snow and ice-core studies at SUNY Buffalo prepared Goto-Azuma to make the most of her first opportunity for fieldwork when it finally arrived.

Goto-Azuma returned to Japan in 1990 and found a postdoctoral position in Professor Masayoshi Nakawo's laboratory at the Institute of Snow and Ice Studies in Nagaoka, where her husband was a member of the faculty at the University of Technology. Goto-Azuma credits Professor Nakawo, who had been supportive of her interests and goals when she was a student, with providing the opportunity to continue in glaciology despite an institutional culture that did not readily accept female scientists.

Two years later, Goto-Azuma realized her long-standing ambition to include fieldwork in her glaciological research, when Shuhei Takahashi invited her to join a field team he was organizing for Shun Kobayashi. The project was as part of Professor Okiitusgu Watanabe's Arctic research program, and her appointment to this post must have come as a surprise to Professor Watanabe, who was not accustomed to thinking of women as scientists. Perhaps Goto-Azuma's work on ice chemistry in northwestern Spitsbergen (GotoAzuma and others, 1993, 1995) influenced his thinking; she reflects that in later years Professor Watanabe became an important supporter of women at the National Institute of Polar Research (personal communication from K. GotoAzuma, 2010). With Svalbard as a stepping stone, she went on to work with Roy (Fritz) Koerner in the Canadian Arctic, a partnership that allowed Goto-Azuma to hone her field skills and prepare to lead her own research programs. In 1998, she was appointed Associate Professor at the Japanese National Institute of Polar Research and, as of this writing, has participated in or led 17 field campaigns in the Arctic, Antarctic and China.

When Kumiko Goto-Azuma began her university studies, women with scholarly interests were directed toward junior colleges or into fields thought suitable for a group whose primary function in society was to become a wife and mother. 
While women now make up about $25 \%$ of all science majors at Japanese universities, their proportions within the disciplines have changed very little (Ogawa, 2006). Yet GotoAzuma made wise use of every opportunity she found, was able to set aside the harassment and lack of respect that greeted her intrusion into what was understood by its inhabitants to be a male domain, and was willing to wait out the long cycle of postdoctoral and temporary positions common for female scientists in Japan (Normile, 2006). She benefited from the support of a husband who expected her to continue with her research after marriage, and from the mentorship of individuals who did not share the prejudices of their contemporaries. Today, she is one of the 11 women out of every 100 scientists in the Japanese workforce.

\subsubsection{Legacy of the Soviet IGY}

Participants in the late 19th-century Russian 'Nihilist' movement viewed the natural sciences as the ultimate source of truth and progress, and thus important to their socio-political goals (Vucinich, 1970, p. 14). Their enthusiasm found a ready opportunity in Tsar Alexander II's late 1850s investment in training (male) scientists as rapidly as possible. The influx of young Nihilists into science classrooms created a welcoming environment for women, although, as elsewhere, the first women admitted to Russian universities were limited to auditor status (Koblitz, 1988). Barred from the university when Alexander II put down student demonstrations in 1861, Russian women traveled to western Europe, primarily to Switzerland, where foreign students could be admitted to university without an entrance exam (Koblitz, 1988). This was an important circumstance for women who did not have access to formal preparatory training at home. The Russians were pioneers of women's education in Europe, but the opportunity came at a price, especially in Switzerland where Russian women faced discrimination in public and harassment by non-Russian men in the classroom (Koblitz, 1988). Nevertheless, hundreds of women persevered, motivated by both their desire to learn and their progressive social philosophy.

Russian women at home organized a series of campaigns intended to win university education for themselves (Engel, 2000, p. 60-61). The eventual result was the founding, in 1878, of the Bestuzhev Higher Women's Courses, named for the first director, Professor K.N. Bestuzhev-Ryumin. Enrollment was restricted, women received no state support to attend and teachers often volunteered their time. Course offerings began to be restricted in 1886, were abolished in 1889 and then resurrected in 1906. The Higher Courses transitioned into the Third Petrograd University in 1918, and that organization was, in turn, merged with others to form the Petrograd State University in 1919. From that time on, although their fortunes followed trends in national politics, women maintained their access to university education with support from the state (Vucinich, 1970).

Many new opportunities became available in Soviet snow and ice research during the IGY (1957-58) and the International Hydrological Decade that followed (196574) (Bulkeley, 2008). Women participated in all aspects of IGY planning, operations and data analysis. Two women, V.A. Troitskaya and N.P. Ben'kova, were members of the national IGY committee, more than a dozen others led major IGY projects, and many more appear as lead authors of IGY-era papers. This was possible because well-trained women were ready to take on the challenge.
A number of remote research stations, established or improved during the IGY, served as hubs for research activities conducted in the field and in the laboratory. Women were well represented in these efforts, although in Antarctica, as was typical at the time, women did not go ashore. University of Leningrad lecturers Nina Konkina and E.S. Lebedeva, together with V.N. Koleshnikova from the University of Moscow, helped establish the high-altitude IGY Fedchenko glacier stations in the Pamir mountains, Tajikistan (Kazanskiy and Kolesnikova, 1961; Kolesnikova, 1962; Konkina, 1967). Elizabeth S. Troshkina, V.A. Voloshina and others participated in the Moscow State University field program at Elbrus mountain in the western Caucasus. Glaciological studies on Elbrus included glacier mass balance, ice mechanics and glacier hydrology (Blinova, 1961; Troshkina and Machova, 1961; Voloshina, 1961). Irina Markova Lebedeva investigated glaciers in the relatively unexplored Polar Ural Mountains, where the Academy of Sciences Institute of Geography established an IGY station near the headwaters of the Khodata river (Dolgushin, 1961; Lebedeva, 1961).

Thirty-one glaciers in the Tien Shan were selected for monitoring and many more were visited during the IGY (Zabirov, 1961). The alpine Physico-Geographical Station established in 1948 by the Soviet Academy of Sciences and carried forward by the Kirghiz Academy of Sciences after 1955 served as a base for many field studies. M.I. Iveronova studied glaciers, debris flows and avalanche in the Tien Shan (Iveronova, 1958). This was a continuation of work she began long before the IGY (Iveronova, 1950).

In contrast to China, where the early generations of female glaciologists have not been replaced over time, Russian women continue to be well represented in glaciology, although they rarely rise to the highest levels of leadership. Paleoglaciologist Olga Solomina, Corresponding Member of the Russian Academy of Sciences, is a notable exception in that regard. Many of the women who published their first papers in the IGY era are still active or only recently retired. Unfortunately, attempts to arrange interviews for this paper were unsuccessful.

\section{CONCLUSION}

Throughout history, women seeking advanced education and work in the sciences and mathematics have faced challenges in finding appropriate preparatory training, admission to universities and, eventually, employment in their chosen disciplines (Rossiter, 1980). These challenges are amplified by low economic status and racial prejudice. When women's education is valued, it is often for benefits external to the individuals themselves. Echoing sentiments expressed around the world, the late 19th-century progressive Indian civic leader Dyal Singh Majithia campaigned for girls' education: 'the object of female education in this country is not to make sound scholars but to make better mothers, sisters and wives' (T. Rajagopalan, http://www. hinduonnet.com/2001/10/09/stories/13090178.htm). Such rationales for women's education persist to the present day, notably with respect to the developing world (Zwart, 1992).

Wherever opportunity arose, due to labor shortages, economic disincentives for men, or legal incentives for universities and employers, women found places on the scientific stage. When the the socio-economic environment changed, women often found themselves back in the wings. This pattern is not unique to the sciences but is found in most 
employment sectors throughout recorded history (Bennett, 2006). Women like Louise Arner Boyd, Hilda Richardson and Elizabeth Morris were able to create leading roles for themselves by rearranging the stage. More commonly, women adapted themselves to fill the space available. The story, as historians of women report, is about change, not transformation.

An effort has been made in the present contribution to look as far back in time as possible with as wide a lens as possible, yet certainly some 'pioneer' women in glaciology have been omitted. Women in the Global South are largely missing here, as are groups who only started to gain access to the scientific laboratory late in the 20th century. The proportion of papers authored by women in IGS publications hovered steadily around 5\% for the first three decades of the record and is still below $20 \%$ (Fig. 9). A metric such as membership in the IGS is less rigorous with respect to scientific accomplishment, introduces an economic bias beyond that associated with obtaining advanced education and is not investigated here.

Many of the successful scientists discussed in the present contribution chose to remain single or without children. As a rule, married women's scholarly pursuits have throughout history been secondary to the activities of their husbands, but it is important to recognize that within the 'trailing career' framework, women actively negotiated for the best possible options. Ebba Hult De Geer's university education was cut short by marriage, a bargain she made in order to gain a permanent appointment under circumstances in which independent female scholars were not accepted. Kathleen Lonsdale and Jean Grove both balanced career and family life by adapting their research agendas to fit the needs of family and by hiring domestic help. Eleanora Bliss Knopf taught private courses from her husband's office at Yale when the university denied her official status. Yang Zhenniang and her colleagues reflect that after 1949, Chinese women gained equal opportunity in science but unequal expectations regarding household responsibilities went unchallenged and unchanged. Kathleen Lonsdale wrote in 1971 that the female scientist 'must be willing to accept additional responsibility' if she wants to succeed. Imbalanced expectations regarding childcare and other household duties persist to the present day, and while the career tracks of male scientists in dual-career families benefit from married status, women's careers do not (Fuchs and others, 2001; Canizares and Shaywitz, 2010).

In some cases, early supporters of equity in science helped create opportunities for women in glaciology. Such support was usually inspired by requests made by the women themselves. In all cases, those opportunities were only meaningful because there were women trained and ready to take them. Reflecting on her interactions with men in positions of relative power, Liz Morris (personal communication, 2010) notes, 'When I say he was a good boss ... he should have been a good boss'. That is, lack of prejudice should be common, not a sign of exceptional character. In all cases, a supportive mentor, female or male, was important to the success of women introduced here.

Glaciology today embraces a highly specialized set of disciplines. To understand women's participation in glaciology, we must understand women's access to the fields of study leading toward those specializations, primarily math and the physical sciences. Within the sciences, sex distribution among disciplines varies widely, following patterns

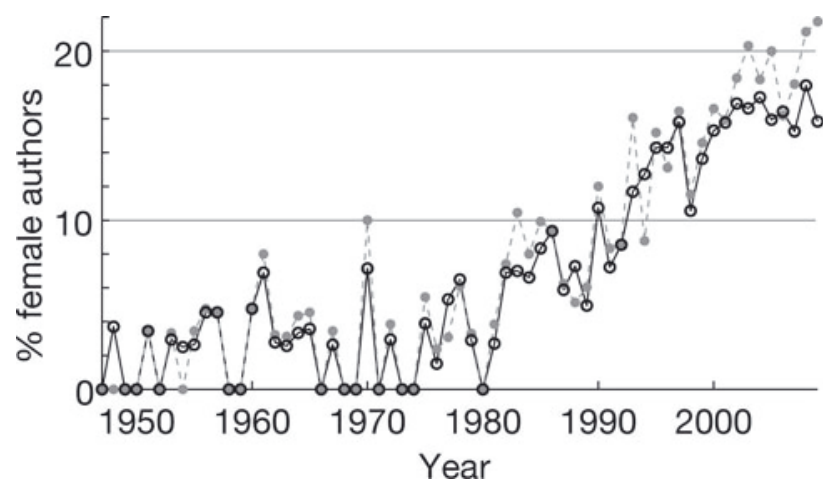

Fig. 9. Percentage of classified Journal and Annals papers authored by women, calculated using the data in Figure 1. Total authorships are in black and first authorships are in grey.

set in place when women gained access to the university in the late 19th and early 20th centuries. Women are relatively well represented in the life sciences, approaching parity with men in some countries, and scarce in the physical sciences (Kuwahara, 2001; European Commission, 2009a; Canizares and Shaywitz, 2010).

Today, far more women train for careers in the sciences than obtain them. From the mid-20th century onward, governments have crafted laws to promote equity in education, first in the Soviet bloc and China and then later in the West and beyond. Yet gender parity in the sciences and the broader labor market has nowhere been achieved, and where women have entered the sciences in significant numbers, they have tended to remain in supporting, not leading, positions (Etzkowitz and Kemelgor, 2001; Blickenstaff, 2005; Epstein, 2007). Where they exist, exceptions can be explained by strong socio-economic forcings. For example, women occupy about $50 \%$ of academic positions in Argentina, where decades of political intervention have resulted in an unstable work environment and low faculty salaries unattractive to men but deemed acceptable for women (Perona, 2009). Nevertheless, Argentine women are under-represented in the physical sciences and do not rise to senior positions at the same pace as their male colleagues (Vilte and Perales, 2007).

The sex biases highlighted by female correspondents to Science a century ago (Hayes, 1910; Talbot, 1910) certainly remain on display today (Andrews and others, 2010; Herbers, 2010), but most academic analyses of women's status in the sciences emphasize more subtle, systemic issues (Etzkowitz and Kemelgor, 2001; Blickenstaff, 2005). Women whose ability equals that of their male counterparts are lost at every transition point along what has been called a 'leaky pipeline' from secondary school, through university, and into academic and research careers (Blickenstaff, 2005; European Commission, 2009b). A growing body of literature examines factors that may affect girls' and women's progress: for example, bias in curricular materials and pedagogy, the availability of role models, cultural norms for gender-appropriate behavior, and harassment (Blickenstaff, 2005; European Commission, 2009b). Women in majority ethnicities and with higher economic standing may be concerned primarily with career advancement, while for women in minority ethnic groups or with lower economic status, simply gaining access to higher education may be in the forefront (Ainuddin and others, 2005). 
A growing number of reports issued by governments and research institutes concerned about impending labor shortages in science and engineering emphasize the need to train and retain women (Mendoza and Johnson, 2000; Ogawa, 2006; European Commission, 2009b). That rationale is not far removed from the 'good wife, wise mother' framing of generations past, in that it places value not in women's intellectual fulfillment but in their service to others, a traditional view of women's role in society. Historians may in the future reference such reports as evidence of an economic forcing that produced space for women in the scientific labor force of the early 21 st century. Such spaces, in decades and centuries past, were transient. In the United States today, concern is raised in the popular media about the negative social effects of women gaining a stronger footing in the workplace and the classroom (C.H. Sommers, http://www.theatlantic.com/magazine/archive/2000/05/thewar-against-boys/4659/; H. Rosin, http://www.theatlantic.com/magazine/archive/2010/07/the-end-of-men/8135/). This echoes economic recessions past, when the cure for unemployment among men was to send women back to the home (Tournier, 1973; Kuwahara, 2001; Monk, 2004; Maddrell, 2008; Baldwin, 2009).

Biological determinism, a long-standing justification for women's low participation in or active exclusion from the sciences, has emerged recently in the popular discourse regarding women's continued under-representation in science. Popularizations of evolutionary psychology and neurobiology suggest men and women possess different 'ways of knowing' and that women are ill-adapted on evolutionary grounds for science and the competitive environment of the laboratory (Brizendine, 2006; Ceci and Williams, 2006). Both parts of the thesis, women's 'inherent' traits and the 'male' culture of the scientific laboratory, should be questioned, as they were in centuries past (Wollstonecraft, 1796; Mozans, 1913). Critical analyses of the recent literature discount the notion of sex differences in cognitive ability and instead conclude that women tend not to persist in math-intensive fields, even where they begin along such academic tracks, due to choices that women, but not men, are compelled to make in modern societies (Young and Balaban, 2006; Ceci and Williams, 2009). Persistent cultural framing of math and physical sciences as male fields is also found to be important in driving the choices girls and women make regarding education and careers in mathematics and the sciences.

It is tempting to use late 20th-century trends in women's participation in the sciences to predict future growth or as evidence that equity is at hand. Yet doing so requires us to ignore much of the history of women's access to education, work in the sciences, and the paid workforce. Careful reading of that history shows that economic and sociopolitical forcings drive access. The same forcings remain at work today (Ceci and Williams, 2009). While progress has recently been made, women remain under-represented in math and the physical sciences, and the social context for that status has not changed, despite hard-won gains of the late 20th century.

\section{ACKNOWLEDGEMENTS}

The authors thank Magnús Már Magnússon, Ken Cruikshank and Scott Waibel for assistance with the IGS authors database. We thank Atsumu Ohmura for his assistance with interviews. Gracias to Olga Nasello for helping us learn about Laura Levi and for patience with C.L.H.'s rudimentary Spanish. Thanks to Julie Palais for insight into polar exploration and to Teresia Teaiwa for the Pacific view. C.L.H. is particularly indebted to Dr Ann Little for her assurance during the review process that both history and historiography matter. C.L.H. was supported by US National Science Foundation (NSF) Office of Polar Programs (OPP) grants No. 0838810 and 0538015.

\section{REFERENCES}

Ainuddin, N., M. Gomes de Carvalho, P. Fan, G. Kelar, I. Munder and M. Taeb. 2005. Revisiting women's participation in science and technology: emerging challenges and agenda for reform. Yokohama, United Nations University Institute of Advanced Studies.

Aldrich, M.L. 1993. Women in geology. In Kass-Simon, G. and P. Farnes, eds. Women of science: righting the record. Bloomington, IN, Indiana University Press, 42-71.

Alexander, S. 2000. Men's fears and women's work: responses to unemployment in London between the wars. Gender Hist., 12(2), 401-425.

Andors, P. 1975. Social revolution and women's emancipation: China during the Great Leap Forward. Bull. Concern. Asian Schol., 7(1), 33-42.

Andrews, N.C., S. Kornbluth and D. Stokke. 2010. Women: diversity among leaders is there if you look. Nature, 463(7281), 608.

Arias, D., L. Levi and L. Lubart. 1966. Electrical properties of ice doped with $\mathrm{NH}_{3}$. Trans. Faraday Soc., 62(523), 1955-1962.

Ariki-tara-are, T. 1919. History and traditions of Rarotonga, Part VI. J. Polynes. Soc., 28(111), 134-151.

Astbury, W.T. and K. Yardley. 1924. Tabulated data for the examination of the 230 space-groups by homogeneous X-rays. Philos. Trans. R. Soc. London, Ser. A, 224(616-625), 221-257.

Bailey, E.B. 1943. Gerard Jacob De Geer. 1858-1943. Obit. Not. Fell. R. Soc., 4(12), 475-481.

Balchin, W.G.V. 1960. Beaches and coasts by Cuchlaine A.M. King (review). Geogr. J., 126(2), 231.

Baldwin, M. 2009. 'Where are your intelligent mothers to come from?': marriage and family in the scientific career of Dame Kathleen Lonsdale FRS (1903-71). Notes Rec. R. Soc. London, 63(1), 81-94.

Bennett, J.M. 2006. History matters: patriarchy and the challenge of feminism. Philadelphia, PA, University of Pennsylvania Press.

Bergwik, S. 2009. Photo essay: making things invisible. Newsl. Hist. Sci. Soc., 38(2).

Blickenstaff, J.C. 2005. Women and science careers: leaky pipeline or gender filter? Gender Educ., 17(4), 369-386.

Blinova, V.L. 1961. Comparison of chemical composition of the ice and water of some glaciers of the Caucasus and Middle Asia. Data Glaciol. Stud., Chron. Discus. 6, 144-148.

Boyd, L.A. 1932. Fiords of east Greenland: a photographic reconnaissance throughout the Franz Josef and King Oscar Fiords. Geogr. Rev., 22(4), 529-561.

Boyd, L.A. 1948. The coast of northeast Greenland with hydrographic studies in the Greenland Sea. The Louise A. Boyd expeditions of 1937 and 1938. New York, American Geographical Society.

Brizendine, L. 2006. The female brain. New York, Morgan Road Books.

Broaded, C.M. and C. Liu. 1996. Family background, gender and educational attainment in urban China. China Q., 145, 53-86.

Bulkeley, R. 2008. Aspects of the Soviet IGY. Russ. J. Earth Sci., 10(1), ES1003. (10.2205/2007ES000249.)

Bullock Workman, F. 1906. First exploration of the Hoh Lumba and Sosbon Glaciers: two pioneer ascents in the Himalaya. Geogr. J., 27(2), 129-141. 
Bullock Workman, F. 1912. Survey of the Siachen Glacier. Bull. Am. Geogr. Soc., 44(12), 897-903.

Bullock Workman, F. and W.H. Workman. 1900. In the ice world of the Himalaya. London, T. Fisher Unwin.

Burek, C. 2009. The first female Fellows and the status of women in the Geological Society of London. In Lewis, C.L.E. and S.J. Knell, eds. The making of the Geological Society of London. Bath, Geological Society of London, 373-408. (Special Publication 317.

Campbell, J.D. 2007. Salons, salonnières, and women writers. In Robin, D.M., A.R. Larsen and C. Levin, eds. Encyclopedia of women in the Renaissance: Italy, France, and England. Santa Barbara, CA, ABC-CLIO, 202-205.

Canizares, C.R. and S.E. Shaywitz. 2010. Gender differences at critical transitions in the careers of science, engineering and mathematics faculty. Washington, DC, National Academies Press.

Ceci, S.J. and W.M. Williams. 2006. Why aren't more women in science? Top researchers debate the evidence. Washington, DC American Psychological Association.

Ceci, S.J. and W.M. Williams. 2009. The mathematics of sex: how biology and society conspire to limit talented women and girls. Oxford, etc., Oxford University Press.

Chipman, E. 1986. Women on the ice: a history of women in the far south. Melbourne, Melbourne University Press.

Clark, J.M. 1951. The investigation of a possible method of cirque erosion. IASH Publ. 32 (Assemblée Générale de Bruxelles 1951 - Neiges et Glaces), Tome 1, 215-221.

Clark, J.M. and W.V. Lewis. 1951. Rotational movement in cirque and valley glaciers. J. Geol., 59(6), 546-566.

Coleman, S. 1999. Japanese science from the inside. London, Routledge.

Condorcet, Marquis de. 1791. Cinq mémoires sur l'instruction publique. Paris.

Cortina, R. 1989. Women as leaders in Mexican education. Compar. Educ. Rev., 33(3), 357-376.

Costas, I. 2002. Women in science in Germany. Sci. Context, 15(4), $557-576$.

D'Arcy, P. 2006. The people of the sea: environment, identity, and history in Oceania. Honolulu, University of Hawaii Press.

Darlington, J. and J.S. Mcllvaine. 1957. My Antarctic honeymoon: a year at the bottom of the world. London, Frederick Muller.

De Geer, G. 1912. A geochronology of the last 12000 years. In Comptes rendus du XI Congrès Géologique International Stockholm 1910. Stockholm, International Geological Congress, 241-253.

De Geer, G. 1934. Geology and geochronology. Geogr. Ann., 16, $1-52$.

De Gouges, O. 1791. Déclaration des droits de la femme et de la citoyenne. Paris, de Gouges, $\mathrm{O}$.

De Pizan, C. 2004 [1405]. The book of the city of ladies, transl. Brown-Grant, R. London, Penguin Classics.

Demorest, M.H. 1953. Processes of ice deformation within glaciers. J. Glaciol., 2(13), 201-203/212

Diamond, N. 1975. Collectivization, kinship, and the status of women in rural China. Bull. Concern. Asian Schol., 7(1), 25-32.

Dolgushin, L.D. 1961. Main features of the modern glaciation of the Urals. IASH Publ. 54 (General Assembly of Helsinki 1960 Snow and lce), 335-347.

Dunbar, M. 1975. Interpretation of SLAR imagery of sea ice in Nares Strait and the Arctic Ocean. J. Glaciol., 15(73), 193-213.

Dunbar, M. 1986. Man and ice: experience with the frozen ocean. In Milligan, S. and W.O. Kupsch, eds. Living explorers of the Canadian Arctic: the historic symposium of Arctic scientists, explorers, and adventurers, Toronto, 1978. Yellowknife, N.W.T., Outcrop, The Northern Publishers, 168-182.

Dunbar, M. and K.R. Greenaway. 1956. Arctic Canada from the air. Ottawa, Ont., Queen's Printer. Defence Research Board.
Dunbar, M., T. Armstrong, B. Roberts, C. Swithinbank and V.L. Tsurikov. 1965. Canadian proposal for changes in WMO sea ice terminology. Polar Rec., 12(81), 717-722.

Edwards, L.P. 2000. Women's suffrage in China: challenging scholarly conventions. Pac. Hist. Rev., 69(4), 617-638.

Elgqvist-Saltzman, I. 1998. 'Why are we standing still?': reflections from history. In Mackinnon, A., I. Elgqvist-Saltzman and A. Prentice, eds. Education into the 21st century: dangerous terrain for women? London, Falmer Press, 20-30.

Engel, B.A. 2000. Mothers and daughters: women of the intelligentsia in nineteenth-century Russia. Evanston, IL, Northwestern University Press.

Epstein, C.F. 2007. Great divides: the cultural, cognitive, and social bases of the global subordination of women. Am. Sociol. Rev., 72(1), 1-22.

Etzkowitz, H. and C. Kemelgor. 2001. Gender inequality in science: a universal condition? Minerva, 39(2), 239-257.

European Commission. 2009a. She figures 2009: statistics and indicators on gender equality in science. Brussels, European Commission. Directorate-General for Research Capacities Specific Programme. (EUR 23856 EN.)

European Commission. 2009b. Women in science and technology: creating sustainable careers. Brussels, European Commission. Directorate-General for Research, Science Economy and Society. (EUR 23740 EN.)

Fuchs, S., J. von Stebut and J. Allmendinger. 2001. Gender, science, and scientific organizations in Germany. Minerva, 39(2), 175-201.

Fujimura-Fanselow, K. 1985. Women's participation in higher education in Japan. Comp. Educ. Rev., 29(4), 471-489.

Funk, M., K. Echelmeyer and A. Iken. 1994. Mechanisms of fast flow in Jakobshavns Isbræ, West Greenland: Part II. Modeling of englacial temperatures. J. Glaciol., 40(136), 569-585.

Goegg, M.P. 1884. Switzerland. In Stanton, T., ed. The woman question in Europe: a series of original essays. New York, G.P. Putnam's Sons.

Gold, L.W. 2002. Isobel Moira Dunbar, 1918-1999. Proc. R. Soc. Can., 1(2), 99-102.

Goodman, D. 1989. Enlightenment salons: the convergence of female and philosophic ambitions. Eighteenth-Century Stud., 22(3), Special Issue, 329-350.

Goto, K., T. Hondoh and A. Higashi. 1986. Determination of diffusion coefficients of self-interstitials in ice with a new method of observing climb of dislocations by X-ray topography. Jpn. J. Appl. Phys., 25(3), 351-357.

Goto-Azuma, K., H. Enomoto, S. Takahashi, S. Kobayashi, T. Kameda and O. Watanabe. 1993. Leaching of ions from the surface of glaciers in western Svalbard. Bull. Glacier Res., 11, 39-50.

Goto-Azuma, K. and 6 others. 1995. An ice-core chemistry record from Snøfjellafonna, northwestern Spitsbergen. Ann. Glaciol., 21, 213-218.

Goudie, A. 2001. Obituary. Jean Grove. The Independent, 12 March.

Greenaway, K.R. and S.E. Colthorpe. 1948. An aerial reconnaissance of Arctic North America. Montreal, Qué., Industrial School for the Deaf.

Grove, J.M. 1988. The Little Ice Age. London, Methuen.

Grove, J.M. 2004. Little ice ages: ancient and modern. Second edition. London, etc., Routledge.

Hammond, V. 1992. Opportunity 2000: a culture change approach to equal opportunity. Women Manage. Rev., 7(7), 156-171.

Hansson, H. 2009. Feminine poles: Josephine Diebitsch Peary's and Jennie Darlington's polar narratives. In Hansson, $\mathrm{H}$. and C. Norberg, eds. Cold matters: cultural perceptions of snow, ice and cold. Umeå, Umeå University and Royal Skyttean Society, 105-124

Harada, M. 1993. The Japanese Junior College and the American Community College: a comparative study. (Master's thesis, University of California, Los Angeles.) 
Hawley, R.L. and E.M. Morris. 2006. Borehole optical stratigraphy and neutron-scattering density measurements at Summit, Greenland. J. Glaciol., 52(179), 491-496.

Hawley, R.L., E.M. Morris and J.R. McConnell. 2008. Rapid techniques for determining annual accumulation applied at Summit, Greenland. J. Glaciol., 54(188), 839-845.

Hayes, E. 1910. Women and scientific research. Science, 32(833), 849-888.

The Herald. 1999. Obituary. Moira Dunbar. The Herald (Glasgow), 11 December, 18.

Herbers, J.M. 2010. Women: why just one to represent half the workforce? Nature, 463(7281), 608-609.

Ho, C.W.-C. 1995. The cultivation of female talent. J. Econ. Soc. Hist. Orient, 38(2), 191-223.

Hobbs, W.H. 1936. Review: The fiord region of East Greenland by Louise A. Boyd. J. Geol., 44(1), 105.

Hodgkins, D.M.C. 1975. Kathleen Lonsdale. 28 January 19031 April 1971. Biogr. Mem. Fell. R. Soc., 21, 447-484.

Höhn, M. 1993. Frau im Haus und Girl im Spiegel: discourse on women in the interregnum period of 1945-1949 and the question of German identity. Cent. Eur. Hist., 26(1), 57-90.

Hondoh, T., T. Itoh, S. Amakai, K. Goto and A. Higashi. 1983. Formation and annihilation of stacking faults in pure ice. J. Phys. Chem., 87(21), 4040-4044.

Huffer, E. 2008. Women and navigation: does the exception confirm the rule? Int. J. Mar. Hist., 20(2), 265-284.

Hult De Geer, E. 1954. Geochronology of the deglacial and neothermal ages: a discussion. De Geer's continuous chronology - or a stretched one with interruptions. J. Geol., 62(5), 514-516.

Hult De Geer, E. and H. Wadell. 1928. Late glacial clay varves in Iceland. Geogr. Ann., 10, 297-306.

Hutton, M.J. 2001. Russian and West European women, 18601939: dreams, struggles, and nightmares. Lanham, MD, Rowman and Littlefield.

Iken, A. 1972. Measurements of water pressure in moulins as part of a movement study of the White Glacier, Axel Heiberg Island, Northwest Territories, Canada. J. Glaciol., 11(61), 53-58.

Iken, A. 1974. Velocity fluctuations of an arctic valley glacier: a study of the White Glacier, Axel Heiberg Island, Canadian Arctic Archipelago. (PhD thesis, ETH Zürich.)

Iken, A. 1981. The effect of the subglacial water pressure on the sliding velocity of a glacier in an idealized numerical model. J. Glaciol., 27(97), 407-421.

Iken, A. and R.A. Bindschadler. 1986. Combined measurements of subglacial water pressure and surface velocity of Findelengletscher, Switzerland: conclusions about drainage system and sliding mechanism. J. Glaciol., 32(110), 101-119.

Iken, A., K. Echelmeyer, W. Harrison and M. Funk. 1993. Mechanisms of fast flow in Jakobshavns Isbræ, West Greenland: Part I. Measurements of temperature and water level in deep boreholes. J. Glaciol., 39(131), 15-25.

Iveronova, M.I. 1950. Kamennie gletcheri severnogo Tyan'-Shan [Rock glaciers in north Tien Shan]. Inst. Geogr. Akad. Nauk SSSR, Trudy, 45(1), 69-88. [In Russian.]

Iveronova, M.I. 1958. Determination of changes at the lower end of central Asian glaciers by means of repeated stereo pairs. In Glacier studies during the International Geophysical Year (IGY), 1957-1958: collected papers, Vol. 1. Moscow, Akademii Nauk. IGY Committee, 53-61.

Ives, J.D. and C.A.M. King. 1954. Glaciological observations on Morsárjökull, S.W. Vatnajökull. Part I: The ogive banding. J. Glaciol., 2(16), 423-428/416.

Ives, J.D. and C.A.M. King. 1955. Glaciological observations on Morsárjökull, S.W. Vatnajökull. Part II: Regime of the glacier, present and past. J. Glaciol., 2(17), 477-482.

Jaccard, C. and L. Levi. 1961. Ségrégation d'impuretés dans la glace. Z. Angew. Math. Phys., 12(1), 70-76.

James, E.T., J.W. James and P.S. Boyer, eds. 1971. Notable American women 1607-1950: a biographical dictionary. Cambridge, MA, Belknap Press.
JMW. 1935. Review: The fjord region of East Greenland by Louise A. Boyd. Geogr. J., 85(5), 478-479.

Kazanskiy, A.B. and V.N. Kolesnikova. 1961. Teplovoi balans poverhnosti $v$ doline reki Seldary vblizi konechnoi lednik Fedchenko [Heat balance of the surface of the Sel'dara River valley near the teminus of the Fedchenko Glacier]. In Gliatsiologicheskie Issledovaniia, Sbornik Statei, IX [Glaciology: results section 9]. Moscow, Akademii Nauk. Mezhdurarodnyi Gyeofizicheskii Komitet, 104-110. [In Russian with English summary.]

King, C.A.M. and J.D. Ives. 1955. Glaciological observations on some of the outlet glaciers of south-west Vatnajökull, Iceland, 1954. Part I: Glacier regime. J. Glaciol., 2(18), 563-569.

King, C.A.M. and J.D. Ives. 1956. Glaciological observations on some of the outlet glaciers of south-west Vatnajökull, Iceland, 1954. Part II: Ogives. J. Glaciol., 2(19), 646-651.

King, C.A.M. and W.W. Williams. 1949. The formation and movement of sand bars by wave action. Geogr. J., 113, 70-85.

Knopf, E.B. 1953. 'Processes of ice deformation within glaciers' by the late Max Harrison Demorest. J. Glaciol., 2(14), 297.

Knopf, E.B. and E. Ingerson. 1938. Structural petrology. Geol. Soc. Am. Mem. 6.

Koblitz, A.H. 1988. Science, women, and the Russian intelligentsia: the generation of the 1860s. Isis [Chicago], 79(2), 208-226.

Kolesnikova, V.N. 1962. Issledovaniya po lednik Fedchenko vo vremya MGG [Investigations on Fedchenko Glacier during IGY] Mater. Glyatsiol. Issled. 4, 71-74. [In Russian.]

Konkina, N. 1967. Skrytye lednikov Tsentralnoi Azii. Fedchenko i Zeravshanskii [Hidden glaciers of Central Asia: Fedchenko and Zeravshanskii]. Leningrad, Gidrometeorologicheskoye Izdatelstvo. [In Russian.]

Kuwahara, M. 2001. Japanese women in science and technology. Minerva, 39(2), 203-216.

Lai, Z. 1987. An analysis of the variation trend of the annual runoff on the northern slope of Qilian Shan. IAHS Publ. 168 (Symposium at Vancouver 1987 - The Influence of Climate Change and Climatic Variability on the Hydrologic Regime and Water Resources), 27-36.

Lai, Z. and B. Ye. 1991. Evaluating the water resource impacts of climatic warming in cold alpine regions by the water balance model: modeling the Ürümqi River basin. Sci. China B, 34(11), 1362-1371.

Lebedeva, I.M. 1961. Osnovnye faktory v plavleniya Moskovskii gosudarstvennyi universitet lednik Polyarnogo Urala, v sootvetstvii s zamechaniya, sdelannye $v 1958$ godu vo vremya MGG [Basic factors in the melting of the Moscow State University Glacier in the Polar Urals, according to observations made in 1958 during the IGY period]. In Gliatsiologicheskie Issledovaniia, Sbornik Statei, IX [Glaciology: results section 9]. Moscow, Akademii Nauk. Mezhdurarodnyi Gyeofizicheskii Komitet, 117-123.

Levi, L. 1956. Osservazioni sopra il processo di accrescimiento a spirale in cristalli di bifosfato di ammonio. Nuovo Cimento, 10(3), 484-485.

Levi, L. 1970. Interpretation of the orientation of ice dendrites growing from supercooled water. J. Glaciol., 9(55), 109-116.

Levi, L. 1973. A study of atomic V-steps formed by cleavage on $\mathrm{NaCl}$ crystal surfaces. Philos. Mag., 28(2), 427-446.

Levi, L. 1998. Beppo Levi en Argentina y el Instituto de Matematica de Rosario (1939-1961). Saber y Tiempo, 2(5), 49-69.

Levi, L. and A.N. Aufdermaur. 1969. Orientation of ice crystals grown by accretion on supercooled droplets. In Riehl, N., B. Bullemer and $\mathrm{H}$. Engelhardt, eds. Proceedings of International Symposium on Physics of Ice, September 9-14, 1968, Munich, Germany. New York, Plenum Press, 620-630.

Levi, L. and A.N. Aufdermaur. 1970. Crystallographic orientation and crystal size in cylindrical accretions of ice. J. Atmos. Sci., 27(3), 443-452.

Levi, L., E.M. Achaval and E. Suraski. 1965. Experimental study of non-basal dislocations in ice crystals. J. Glaciol., 5(41), 691-699. 
Levi, L., E. Achaval and A.N. Aufdermaur. 1970. Crystal orientation in a wet growth hailstone. J. Atmos. Sci., 27(3), 512-513.

Lewander, L. 2009. Women and civilisation on ice. In Hansson, H. and C. Norberg, eds. Cold matters: cultural perceptions of snow, ice and cold. Umeå, Umeå University and Royal Skyttean Society, 89-104.

Liu, J. and M. Carpenter. 2005. Trends and issues of women's education in China. Clearing House, 78(6), 277-281.

Lonsdale, K. 1929. The structure of the benzene ring in $\mathrm{C}_{6}\left(\mathrm{CH}_{3}\right)_{6}$. Proc. R. Soc. London, Ser. A, 123(792), 494-515.

Lonsdale, K. 1958. The structure of ice. Proc. R. Soc. London, Ser. A, 247(1251), 424-434.

Lonsdale, K. 1970. Women in science: reminiscences and reflections. Impact Sci. Soc., 20(1), 45-59.

Lonsdale, K. 1971. Women scientists: why so few? Lab. Equip. Dig., 86, February.

Lüthi, M., M. Funk, A. Iken, S. Gogineni and M. Truffer. 2002. Mechanisms of fast flow in Jakobshavn Isbræ, West Greenland: Part III. Measurements of ice deformation, temperature and cross-borehole conductivity in boreholes to the bedrock. J. Glaciol., 48(162), 369-385.

Maddrell, A. 2008. The 'Map Girls'. British women geographers' war work, shifting gender boundaries and reflections on the history of geography. Trans. Inst. Br. Geogr., 33(1), 127-148.

Maddrell, A. 2009. Complex locations: women's geographical work in the UK, 1850-1970. Oxford, Wiley-Blackwell.

Mason, J. 1992. The admission of the first women to the Royal Society of London. Notes Rec. R. Soc. London, 46(2), 279-300.

Mendoza, E.M. and K.O. Johnson. 2000. Land of plenty: diversity as America's competitive edge in science, engineering and technology. Arlington, VA, National Science Foundation. (Report of the Congressional Commission on the Advancement of Women and Minorities in Science, Engineering and Technology Development.)

Meschel, S.V. 1992. Teacher Keng's heritage: a survey of Chinese women scientists. J. Chem. Educ., 69(9), 723-730.

Messbarger, R. 2002. The century of women: representations of women in eighteenth-century Italian public discourse. Toronto, Ont., University of Toronto Press.

Moeller, R.G. 1998. The 'remasculinization' of Germany in the 1950s: introduction. Signs, 24(1), 101-106.

Monk, J. 2004. Women, gender, and the histories of American geography. Ann. Assoc. Am. Geogr., 94(1), 1-22.

Morrell, A.J. 1833. Narrative of a voyage to the Ethiopic and South Atlantic Ocean, Indian Ocean, Chinese Sea, North and South Pacific Ocean, in the years 1829, 1830, 1831. New York, J. \& J. Harper.

Morris, E.M. 1976. An experimental study of the motion of ice past obstacles by the process of regelation. J. Glaciol., 17(75), 79-98.

Morris, E.M. 1981. Field measurement of the liquid-water content of snow. J. Glaciol., 27(95), 175-178.

Morris, E.M. 1999. Surface ablation rates on Moraine Corrie Glacier, Antarctica. Global Planet. Change, 22(1-4), 221-231.

Morris, E.M. 2008. A theoretical analysis of the neutron-scattering method for measuring snow and ice density. J. Geophys. Res., 113(F3), F03019. (10.1029/2007JF000962.)

Morris, E.M. and J.D. Cooper. 2003. Density measurements in ice boreholes using neutron scattering. J. Glaciol., 49(167), 599-604.

Morris, E.M. and A.G. Thomas. 1985. Preferential discharge of pollutants during snowmelt in Scotland. J. Glaciol., 31(108), 190-193.

Morris, E.M. and D.A. Woolhiser. 1980. Unsteady one-dimensional flow over a plane: partial equilibrium and recession hydrographs. Water Resour. Res., 16(2), 355-360.

Mozans, H.J. 1913. Woman in science. New York, D. Appleton.

Murray, J.S. 1790. On the equality of the sexes. Mass. Mag., 2(3-4), 132-135, 223-226.

Ngo, H.-Y. 2002. Trends in occupational sex segregation in urban China. Gend. Technol. Dev., 6(2), 175-196.
Nolte, S.H. 1986. Women's rights and society's needs: Japan's 1931 Suffrage Bill. Comp. Stud. Soc. Hist., 28(4), 690-714.

Normile, D. 2006. Getting women scientists back on the career track in Japan. Science, 311(5765), 1235-1236.

Nye, J. 1997. The Cambridge Austerdalsbreen expeditions 19541963. Ann. Glaciol., 24, 1-5.

Ogawa, M. 2006. Women's careers in science and technology in Japan. In Women in Scientific Careers: Unleashing the Potential. Joint OECD-French Government International Workshop, 16-17 November 2005, Paris, France. Paris, Organisation for Economic Co-operation and Development, 87-94.

Ogilvie, I.H. 1902. Glacial phenomena in the Adirondacks and Champlain Valley. J. Geol., 10(4), 397-412.

Ogilvie, I.H. 1904. The effect of superglacial débris on the advance and retreat of some Canadian glaciers. J. Geol., 12(8), 722-743.

Ogilvie, I.H. 1905. Geology of the Paradox Lake quadrangle, New York. New York State Museum Bull. 96.

Ogilvie, I.H. 1916. Field observations on the lowan problem (Abstract). Ann. NY Acad. Sci., 26, 432-433.

Ogilvie, M.B. 1993. Women in science: antiquity through the nineteenth century. Cambridge, MA, MIT Press.

Ommanney, S. 2001. Obituary. Hilda Richardson. Polar Rec., 37(203), 370-371.

Ortiz, E.L. 2003. La política interamericana de Roosevelt: George D. Birkhoff y la inclusión de América Latina en las redes matemáticas internacionales, primera parte. Saber y Tiempo, 15, 53-111.

Owston, P.G. and K. Lonsdale. 1948. The crystalline structure of ice. J. Glaciol., 1(3), 118-123.

Perona, E. 2009. Women in higher education in Argentina: equality or job feminization? Can. Woman Stud., 27(1), 155-160.

Plonski, G.A. and R.G. Saidel. 2001. Gender, science and technology in Brazil. Minerva, 39(2), 217-238.

Qiao, Y. and K. Liu. 2009. The emerging of 'female citizen': the subject identity of modern Chinese women through literary practices. Front. Hist. China, 4(1), 107-123.

Rayner-Canham, M. and G. Rayner-Canham. 2008. Chemistry was their life: pioneer British women chemists, 1880-1949. London, Imperial College Press.

Robinson, M.F. 2006. The coldest crucible: Arctic exploration and American culture. Chicago, IL, University of Chicago Press.

Ronne, E. 1950. Women in the Antarctic, or the human side of a scientific expedition. Appalachia, 28(1), 1-15.

Ronne, E.M. 2004. Antarctica's first lady: memoirs of the first American woman to set foot on the Antartic Continent and winter-over. Beaumont, TX, Clifton Steamboat Museum/Three Rivers Council.

Rossiter, M.W. 1974. Women scientists in America before 1920. Am. Sci., 62(3), 312-323.

Rossiter, M.W. 1980. 'Women's work' in science, 1880-1910. Isis [Chicago], 71(3), 381-398.

Rossiter, M.W. 1998. Women scientists in America: before affirmative action 1940-1972. Baltimore, MD, Johns Hopkins University Press.

Rousseau, J.-J. 1763. Emilius; or, an essay on education. London, J. Nourse and P. Vaillant.

Sack, D. 2004. Experiences and viewpoints of selected women geomorphologists from the mid-20th century. Phys. Geogr., 25(5), 438-452.

Schiebinger, L. 1987. The history and philosophy of women in science: a review essay. Signs, 12(2), 305-332.

Schiebinger, L. 1991. The mind has no sex? Women in the origins of modern science. Cambridge, MA, Harvard University Press.

Schiebinger, L. and S.K. Gilmartin. 2010. Housework is an academic issue: how to keep talented women scientists in the lab, where they belong. Academe, 96(1), 39-44.

Shahar, S. 2003. The fourth estate: a history of women in the Middle Ages. Second edition. New York, Routledge.

Sharma, J. 2000. Women education in the Upanishads. In Singh, N.K., ed. Encyclopaedia of Hinduism: a continuing series, Vol. 1. New Delhi, Anmol Publications, 1831-1837. 
Shi, Y. 2003. An outstanding hydrologist for glacier and cold regions: Professor Yang Zhenniang. J. Glaciol. Geocryol., 25(1), 112. [In Chinese.]

Somerville, M. 1849. Physical geography. London, John Murray.

Stacco, E.F. 2002. La matemática en la Argentina entre las guerras mundiales. Saber y Tiempo, 4(13), 164-196.

Street, J.H. 1981. Political intervention and science in Latin America. Bull. Atom. Sci., 37(2), 14-23.

Talbot, M. 1910. Eminence of women in science. Science, 32(833), 866.

Thomas, L.B. 1948. Some Manitoba women who did things first. Manitoba Hist. Soc. Trans., 3(4).

Thompson, L.G., X. Wu, E. Mosley-Thompson and Z. Xie. 1988. Climatic records from the Dunde ice cap, China. Ann. Glaciol., 10, 178-182.

Tournier, M. 1973. Women and access to university in France and Germany (1861-1967). Comp. Educ., 9(3), 107-117.

Troshkina, E.S. and J.V. Machova. 1961. Application of the sporepollen analysis for studying the structure of glaciers on Elbrus mountain. IASH Publ. 54 (General Assembly of Helsinki 1960 Snow and Ice), 195-203.

Unger, J. 1980. The Chinese controversy over higher education. Pac. Aff., 53(1), 29-47.

Vaux, M.M. 1911. Observations on glaciers in 1910. Can. Alp. J., 3, 127-129.

Vaux, M.M. 1913. Observations on glaciers. Can. Alp. J., 5, 59-61.

Vaux, M.M. and G. Vaux, Jr. 1911. The glaciers of the Canadian Rockies and Selkirks. Second edition. Bryn Mawr, PA, privately printed.

Vilte, M.D.S. and M.A. Perales. 2007. Pioneras de la ciencia: 'ellas hacen física'. Anales AFA, 19, 17-26.

Voloshina, A. 1961. Radiation and thermal factors in the ablation of glaciers on the southern slope of Elbrus. IASH Publ. 54 (General Assembly of Helsinki 1960 - Snow and Ice), 301.

Vucinich, A. 1970. Science in Russian culture: 1861-1971. Stanford, CA, Stanford University Press.

Wade, N. 1976. Repression in Argentina: scientists caught up in tide of terror. Science, 194(4272), 1397-1399.

Walcott, M.M.V. 1925. North American wild flowers. Washington, DC, Smithsonian Institution.

Wang, Z. 1999. Women in the Chinese enlightenment: oral and textual histories. Berkeley, CA, University of California Press.

Weissmann, M., O. Nasello and L. Lubart. 2003. Laura Levi (19152003). Saber y Tiempo, 4(15), 147-150.
Wheeler, A.O. and E. Parker. 1912. The Selkirk Mountains: a guide for mountain climbers and pilgrims. Winnipeg, Man., Stovel Co.

Winnipeg Free Press. 1944. Mrs Elizabeth Parker dies in her 88th year. Winnipeg Free Press, 17 October, 11.

Wollstonecraft, M. 1796. A vindication of the rights of woman with strictures on political and moral subjects. Third edition. London, J. Johnson.

Wood, P. 1986. The International Glaciological Society: fifty years of progress. Cambridge, International Glaciological Society.

Woods, E.A. 1964. Memorial to Ida Helen Ogilivie (1874-1963). Geol. Soc. Am. Bull., 75(2), P35-P40.

Workman MacRobert, R. 1914. Acid and intermediate intrusions and associated ash-necks in the neighbourhood of Melrose (Roxburghshire). Q. J. Geol. Soc. London, 70(1-4), 303-315.

Wu, L.-A. 2008. China: in their words. Nature, 454(7203), 399-402.

$\mathrm{Wu}, \mathrm{X} .2007$. Application of isotope tritium in the study of ice-snow meltwater, surface water and ground water resources in the Lenglongling Mountain district of the Qilian Mountains. In Hövermann, J. and W. Wang, eds. Reports on the northeastern part of the Qinghai-Xizang (Tibet) Plateau by Sino-W. German Scientific Expedition. Stuttgart, Schweizerbart, 94-111.

$\mathrm{Wu}, \mathrm{X}$. and L.G. Thompson. 1988. A 40 year record in an ice core from the Dunde ice cap, China. Ann. Glaciol., 10, 221.

Yang, Z. 1982. Basic characteristics of runoff in glacierized areas in China. IAHS Publ. 138 (Symposium at Exeter 1982 - Hydrological Aspects of Alpine and High Mountain Areas), 295-307.

Yang, Z., ed. 1991. Glacier water resources in China. Lanzhou, Science and Technology Press of Gansu. [In Chinese.]

Yang, Z. and Q. Zeng, eds. 2001. Glacier hydrology. Chongqing, Chongqing Press. [In Chinese.]

Yang, Z., X. Lui, Q. Zeng and Z. Chen. 2000. Cold regions hydrology in China. Beijing, Science Press. [In Chinese.]

Young, R.M. and E. Balaban. 2006. Psychoneuroindoctrinology. Nature, 443(7112), 634.

Zabirov, R.D. 1961. About the state of some of the Tien Shan glaciers during the period of the International Geophysical Year (IGY). IASH Publ. 54 (General Assembly of Helsinki 1960 Snow and Ice), 405-411.

Zhang, T. and D. Yang. 2008. Tribute: a legendary glaciologist: academician Shi Yafeng on his ninetieth birthday. Arct. Antarct. Alp. Res., 40(3), 600-604.

Zwart, G. 1992. From women in development to gender and development, more than a change in terminology? Agenda, 14, $16-21$. 